\title{
Intellectual Capital Disclosure in Annual Reports of Islamic Banks: A Comparative Study of Malaysia and Indonesia
}

\author{
Agusdiwana Suarni', Fatima Abdul Hamid $^{2}$, Nazli Anum Mohd Ghazali ${ }^{3}$ \\ \{agusdiwana.suarni@unismuh.ac.id ${ }^{1}$ \} \\ Universitas Muhammadiyah Makassar, +6281341568133
}

\begin{abstract}
This study focuses on four specific objectives. Firstly, the study examines the extent and quality of the Intellectual Capital Disclosure (ICD) in the annual reports of Malaysian and Indonesian Islamic banks from 2009 until 2013. Secondly, it aims to examine the categories of ICD (extent and quality) in both Malaysian and Indonesian Islamic banks over time. Thirdly, this study also focuses on the comparison of the ICD of Malaysian and Indonesian Islamic banks during the study period of five years. Fourthly, the study determines the factors that influence the ICD in the annual reports of Malaysian and Indonesian Islamic banks. The extent of disclosure was measured by applying a checklist of 33 items. The results showed that the trend of ICD in the annual reports of Malaysian and Indonesian Islamic banks increased over the five years. Regulation should take these findings into consideration since both Malaysia and Indonesia aim to be Islamic financial hubs.
\end{abstract}

Keywords: Islamic Banks, Indonesia, Malaysia, Intellectual Capital Disclosure (ICD).

\section{Introduction}

\subsection{Background of the Study}

In the era of rapidly changing technology and massive competition, Intellectual Capital (IC) has become an important factor to be considered by companies in the formulation of their organisation [1]. In a knowledge-based economy, intellectual assets such as skilled employees, sound infrastructures, networking systems, information systems, innovations, brand names, trademarks and knowledge bases bring competitive advantages for companies. These intellectual assets are a company's IC. In defining IC, intellectual material consists of knowledge, information, and intellectual property, as well as experience that can be put to use to create wealth [2]. This is because the basis for competition has shifted from traditional physical and financial resources to intangible resources [3]. Thus, a company's intangible properties (typically displayed in the form of skilled people, processes, competencies, and knowledge) provide core foundations of its current and prospective wealth [3]. As a result, these intellectual properties or IC have become a growing research interest in the recent years.

Currently, in a knowledge-based economy, IC has secured overwhelming attention from researchers, academicians, practitioners and entrepreneurs. There are many researchers, such as [4], [5, 6], [7], [8],[9],[10],[11],[12] who have found IC to be the most vital intangible asset for the success of organisations. They have argued that IC will help organisations to sustain competitive advantage, enhance financial performance, and create value. Therefore, IC is important for companies to achieve economic success [13]. 
In addition, [14] classified IC into three categories, which are human capital, internal capital, and external capital. Human capital refers to innovation, flexibility, tolerance, motivation, satisfaction, learning capacity, loyalty, and training. Meanwhile, the internal capital of the organisation could be defined as the knowledge within the organisation, such as intellectual properties, contracts, database, information systems, culture, procedures, manuals, administrative routines and best practices. On the other hand, external capital is the information of brands, customer base, and partnership. After a brief introduction about IC, the following section will provide the problem statement of this study prior to identifying the research objectives and research questions.

\subsection{Problem Statement}

In order to thrive, the banks need to be innovative. The banking sector is also considered a knowledge-intensive sector, as it has to offer innovative and competitive financial products and services. Although IC is crucial in the banking sector, as a whole, this study focuses only on Islamic banks. IC may be considered even more important in Islamic banks as these banks have to offer financial products and services that are not only able to compete with conventional banks, but are also Shari'ah compliant.

Since IC creates value [15], [11], [12] it is important for Islamic banks to relay this information to the investors and stakeholders. It is even more crucial when both Indonesia and Malaysia aim to become international Islamic financial hubs [16]. This is because both Indonesia and Malaysia have large Muslim populations, and hence are prospective financial markets [17].The opinion is in line with [18]: "Perhaps the single most important factor behind the powerful growth of the Shari'ah compliant funds industries lies in the simple fact that the Muslims represent about a quarter of the world's population". For instance, in Indonesia, being the largest Muslim country in the world, Indonesia experiences rapid growth in its Islamic banking industry [19]. Regardless of the rapid growth locally, it is uncertain whether the Islamic banks in these two countries are making sufficient disclosure, particularly on IC, which will signal their value creation. Also, due to their aim of becoming an international Islamic financial hub, these two countries seem to be in competition to attract investors. So far, there are no evidences to suggest the extent of quality of their Intellectual Capital Disclosure (ICD) which would allow a comparison of their signalling ability to create value.

Islamic banks are founded on the basis of the Shari'ah: thus, these banks are accountable not only to their stakeholders, but also to the Ummah and ultimately to the Creator [20].Therefore, these banks need to disclose information regarding their performance to society to discharge their accountability. This is also true in the case of ICD. However, [21], [22], [23], [19], [24], all found that the levels of transparency in annual reports of Islamic banks are quite low. Low ICD may also be true in Islamic banks. Since Indonesia and Malaysia aim to become Islamic financial hubs, it would be disadvantageous if it is found that Islamic banks in these countries have low ICD.In order to possibly alleviate the problem of low disclosure, some corporate governance mechanisms may be able to monitor the transparency of disclosure, including of IC. However, these mechanisms, specifically of Shari'ah Committee (SC), which is directly relevant to Islamic banks, as well as audit committee and board of directors, have not been tested in the context of ICD of Malaysian and Indonesian Islamic banks. Thus, there is no empirical evidence to suggest which of these mechanisms may be effective in enhancing ICD. This study attempts to address some of the problems stated above. Hence, the next section specifies the objectives and research questions of this study. 


\subsection{Research Objectives and Research Questions}

This study has the following research objectives:

RO 1: To examine the extent and quality of ICD in the annual reports of Malaysian and Indonesian Islamic banks from the years 2009 to 2013.

RO 2: To examine the categories of ICD (extent and quality) in both Malaysian and Indonesian Islamic banks over time.

RO 3: To compare between ICD in annual reports of Malaysian and Indonesian Islamic banks from 2009 until 2013.

RO 4: To identify the determinants ICD in the annual reports of Malaysian and Indonesian Islamic banks.

Based on the research objectives, this study is undertaken to answer the research questions of the study, which are formulated as follows:

RQ 1: What is the extent and quality of ICDs in the annual reports of Malaysian and Indonesian Islamic banks from the years 2009 to 2013 ?

RQ 2: What are the categories of ICD (extent and quality) in Malaysian and Indonesian Islamic banks?

RQ 3: Is there any differences in ICD of Malaysian and Indonesian Islamic banks?

RQ 4: What are the determinants of ICD in the annual reports of Malaysian and Indonesian Islamic banks?

\section{Literature Review}

\subsection{Definition Of IC}

IC is elusive, but once it is discovered and exploited it may provide an organisation with a new resource base from which to compete and win [25], [26] defines IC as the term given to the combined intangible assets, intellectual property, human-centred and infrastructure which enable the company to function. [27] explain that IC includes all the processes and assets which are not normally shown on the balance sheet, and all the intangible assets (trademarks, patents and brands) which modern accounting methods consider. It includes the sum of the knowledge of its members and the practical transactions from that knowledge. Meanwhile, [2]explained that IC is an intellectual material which comprises knowledge, information, intellectual property, and experience that can be put to use in creating wealth. Therefore, IC can be defined as a strategic ecosystem for a company, which can be used to create value.

\subsection{Classification Of IC}

This section discusses the classification of IC. IC is classified into three categories which are internal capital, external capital, and human capital. Internal capital consists such categories as intellectual property (e.g. patents, copyrights, and trademarks), and infrastructure assets (i.e. management philosophy, corporate culture, management processes, information systems, networking systems, and financial relations). External capital consists business partnering and alliances (e.g. brands, customers, customer loyalty, customer names, distribution channels, business collaborations, licensing contracts, and franchising agreements).

In addition, human capital refers to education levels (i.e. average education level), employees' welfare (i.e. information about share options schemes), training and education 
(e.g. information about the training programmes, training costs, programmes, education costs), knowledge map (i.e. know-how), employees capacities and development plans, and the safety of employees. After providing a definition and classification of IC, the next discussion will elaborate on some of the existing literature on measuring IC. It is believed that providing such a discussion before reviewing the empirical literature on IC disclosure (ICD) would help to enhance an understanding of IC.

\subsection{Measurement Of IC}

Prior studies that focused on the method of measurement of IC include [28], [29], [30], [31], [32], [34]. Consequently, there have been some attempts to develop models or methods which measure a company's IC ([35]; [36]; [37]; [38]). One of the first models developed was the Balance Scorecard (BSC) by [28]. The BSC aims to measure the company's performance using both financial and non-financial measurement. The BSC tries to link the visions and strategies of the company. Another method, developed by [29] was the Value Platform (VP). The model identifies three types of IC which include human capital, organisational capital, and customer

capital. A year later, [30] developed a model called the Intangible Asset Monitor (IAM). The IAM is a model for measuring intangible assets and a presentation format which presents a number of relevant indicators based on a company's strategy [30].

In the same year as [30], [31] proposed the Skandia Navigator (SN) model. The development of the model started in 1993. The model developed the Skandia Market Value Scheme (SMVS) framework introduced by [31]. Based on the SMVS, market value is divided into financial capital and IC. The IC categories are divided into structural capital and human capital. Structural capital represents the internal and external relationships of focus. It comprises two categories which are customer capital and organisational capital, which include innovation capital and process capital. Innovation capital refers to things which generate success in the future. Process capital refers to the knowledge in the company.

The development of the SN model is based on concepts developed by Sveiby in his model of the invisible balance sheet. Furthermore, [32] introduced the Intellectual Capital Index (ICI). IC index is linked to shareholders and value creation. In addition, the Value Added Intellectual Capital Coefficient (VAIC) was proposed by [33]. He adopted the same framework of the company value proposed by [32] and [31]. The value consisted of capital employed (i.e. financial, physical capital and intellectual capital) [36].Hence, IC is divided into human capital and structural capital. [39] mentioned that the VAIC provides information on the value creation efficiency of the physical and intellectual capital of the company. Therefore, the VAIC model does not measure the IC of a company, but measures the efficiency of the company [40] which is consistent with the opinion that the VAIC is "an analytical procedure designed to enable management, shareholders, and other relevant stakeholders to effectively monitor and evaluate the efficiency of value added (VA) by a company's total resources and each major resource component" [41].

The VAIC is the VA efficiency of IC coefficient for a company which is a composite sum of three efficiency coefficients, namely Capital Employed (i.e. physical and financial capital) Efficiency (CEE), Human Capital Efficiency (HCE), and Structural Capital Efficiency (SCE). CEE is an indicator of VA efficiency of capital employed, HCE is an indicator of the VA efficiency of human capital, and SCE is an indicator of structural capital. Therefore, the formula for VAIC is CEE + HCE + SCE ([33]; [41]).

The Economic Value Added (EVA) was proposed in the late-1980s by a consulting company, Stern Stewart and Co. [27]. The EVA is a comprehensive method of performance 
measurement which uses capital budgeting, financial planning, goal setting, performance measurement, shareholder communication and incentive compensation together to calculate the corporate value that can be added or lost ([27]; [35]). The model provides a good association with share price. In addition, the model provides a link between financial planning, budgeting, goal setting and compensation ([42]). The EVA model consist 164 areas of performance adjustments which solve weaknesses in the current (conventional) accounting systems, including areas such as depreciation, capitalisation and amortisation of R\&D and acquisition premiums [27].The EVA is measured by the difference between net sales and operating expenses, taxes, and capital charges (i.e. weighted average cost of capital multiplied by the total capital invested).

Finally, the Market-to-Book Value (MBV) is the simplest method to measure the IC of a company [2].The MBV is considered to be a market tool to measure the IC of a company, which is based on capital markets' premium and share price [42]. Therefore, IC is calculated as the difference between the market value (MV) and book value (BV) of a company [56]. The formula is $\mathrm{IC}=\mathrm{MV}-\mathrm{BV}$.

\subsection{Comparison Of ICD Practices Between Countries}

Some of the studies have made a comparison of ICD practices between countries, such as [6], [43], [44], [45] [46], [47], [48], [49], [6] studied the ICD of Danish, Swedish and Spanish companies. The study found that only Spanish companies are performing knowledge management and intellectual capital measuring and reporting. Meanwhile, a study on ICD in The Netherlands, Sweden and UK was conducted by [43]. The samples of this study are 20 companies in The Netherlands, 20 companies in Sweden, and 100 UK companies from 1998, 2000 and 2002. The findings of this study are that Swedish companies have more disclosure compared to The Netherlands and UK companies. The analyses of IC categories indicated that overall disclosure of external capital $(40 \%)$ was higher than internal $(30 \%)$ and human capital (30\%). On average, ICD increased over the years in all three countries.

In addition, [44] conducted a conceptual study to examine the ICD in Australia and Hong Kong in 1998 and 2002. The samples are 20 Australian companies in 1998 and 50 in 2002. On the other hand, there was only a sample in 2002 for Hong Kong, comprising 100 companies. The findings showed that the levels of voluntary IC were found to be low and qualitative rather than quantitative, in both Australia and Hong Kong. Furthermore, the disclosure level was positively related to company size, industry and time. Returning to Italy and the UK, [45] examined the determinants (size, leverage, ownership structure, industry and profitability) of ICD. The study found that size and industrial sector had a positive relationship to the level of ICD; however, nationality of origin to ICD was not significant. Another study of determinants of ICD conducted by White et al. (2010) compared between Australia and the UK. This study examined leverage, size and country. This study found that leverage affected ICD in UK and Australian companies.

[47] studied nine European countries, France, Spain, UK, Germany, The Netherlands, Italy, Norway, Denmark and Sweden, in 2003. The finding of this study is that ICD varies within the study's sample. Moreover, French banks had the highest ICD, and Danish banks had the lowest. The disclosure from the categories of IC is quite low, which is about $30 \%$ of ICD. Another finding is that structural capital was slightly higher than human and relational capital, and that IC information was found in all sections of the annual reports. A study was conducted by [50]. The sample of this study was compared to developing (Sri Lanka) and developed (Australia) countries. The result identified that ICDs need a uniform definition and reporting framework that provides comparative and consistent reporting, monitored by 
regulatory bodies. Also ICD differences are identified between Sri Lankan and Australian companies. It is argued that these differences can be attributed to economic, social and political factors. Later, [51] compared ICD between Singapore and Sri Lanka. Similar to his previous study, he found that there was a difference between ICD in Sri Lanka and that in Singapore. He once again highlighted that IC framework needs uniform ICD practices.

[49]conducted a study comparing companies in India and Australia. The study examines the trend of ICD. The finding was that there was a difference in ICD between Indian and Australian companies in 2007 and 2008. Australian companies had lower disclosure compared to Indian software and technology sector companies. The level of voluntary ICD in India and Australia was low and most of the disclosures were declarative in nature. The main findings support the existence of a difference in ICD.

Table 1. Summary of the Literature on Measurement of IC in General Measurement

\begin{tabular}{l}
\hline Balance Scorecard (BSC) [28] \\
Value Platform (VF) [29] \\
The Technology Broker (TB) [25] \\
Intangible Asset Monitor (IAM) [30] \\
Skandia Navigator (SN) [31] \\
Intellectual Capital Index (ICI) [32] \\
Value Added Intellectual Capital \\
Coefficient (VAIC) [33] \\
Economic Value Added (EVA) [34] \\
Market-to-Book Value (MBV) [2] \\
\hline
\end{tabular}

\subsection{ICD Studies In The Banking Sector}

There are some studies which have discussed ICD, specifically in the banking sector, such as [52], [53], [54]. These studies examined the trend of ICD and found that ICD increased over the years. In addition, [54] examined the determinants of corporate governance (i.e. board size, independent non-executive directors, board meetings, director ownership, governance ownerships, size, and profitability) on ICD in annual reports. This study found that all the corporate governance variables and ownership structures had a significant positive effect on ICD. In addition, [53] wrote a paper on the trends of ICD in the Nigerian banking sector. The study examined the ICD practices of Nigerian banks longitudinally, following the restructuring exercise, and the subsequent policy changes in the banking sector. They found that the overall ICD of the Nigerian banks increased moderately over the four-year period (2006-2009). Human and internal capital disclosure dominated the banks' ICD, with only internal capital disclosure showing a significant increasing trend over time. Therefore, the discussion above clearly identified that the prior studies of ICD, especially in the banking industry, still need further research. In addition, recognition and disclosure of intellectual capital is still in development stage.

Based on the previous literature, most of studies on ICD (e.g. trend, extent, quality and categories) have been conducted on companies ([08]; [52]; [53]; [54]; [55], [56], [57], [58] [59]). There is a lack of studies on ICD in banks, especially on Islamic banks. Therefore, this study focuses on Islamic banks. This is related to the first and second objective of the study. Furthermore, literature reveals that there is a dearth of comparative studies ([60]; [45]; [46]; [47]; [48]; [49]; [50]; [51]). Thus, a study on ICD that compares the case of Malaysia and Indonesia is timely, specifically in the Islamic banking sector. This is because both countries 
aim to be an international Islamic financial hub, hence may be competing for investors. This is linked to this study's third objective. Therefore, a potential research area is ICD in Islamic commercial banks' annual reports: a comparative study in Malaysia and Indonesia from 2009 until 2013. In addition, most of the prior literature found the determinants of ICD as firm size, industry type and leverage [26].Prior literature has not considered certain variables on SC that are relevant to the context of Islamic banks. Hence, this study adds independent variables on $\mathrm{SC}$ (i.e. number of SC, experience on other on SC (EOSC) and educational and qualification). This is related to the fourth objective of this study.

\subsection{The Theoretical Framework Of ICD}

This section discusses the theoretical framework adopted in this study, which can help to explain why Islamic banks would disclose more IC information. Agency theory and Islamic accountability theory are used to explain the disclosure practices of companies and ICD in particular. The hypotheses will be developed from these theories.

\subsubsection{Agency Theory}

Agency theory is among the theories widely-used by accounting researchers, particularly in the financial reporting disclosure area. This theory addresses the relationship between a principal and an agent. It is a theory of agency relationship. [61] described the agency relationship as an agreement under which one party (principal) or more engages the other party (the agent) to conduct and operate the business operation on its behalf. They argued that, since there is a separation between the principal and the agent, the agent may not always behave in the best interests of the principal, as there could be a conflict of interest between both parties. In order to reduce the possibility of the agents (managers) not behaving in the interest of principals, agency costs are incurred by the principles (shareholders).

Agency costs could be reduced with proper monitoring. However, it is difficult for principals to monitor their agents as information asymmetry exists between them. Generally, information asymmetry occurs in most business settings; managers have more information and know more about the business than the principals (shareholders), since they (the managers/agents) are directly involved in the daily running of the business. The agent tends not to disclose some information as to protect their own interest, although such information could be valuable and demanded by the other party. [62] stated that financial reporting disclosure could reduce information asymmetry between the contractual parties in the principal-agent relationship. Hence, in order to reduce agency costs, more disclosure is needed.

Therefore, agency theory has been widely used to explain why companies disclose more information voluntarily [78] The use of agency theory in explaining more disclosure in general, and ICD in particular can be seen when those holding monitoring roles ensures that the company discloses more information to stakeholders to alleviate information asymmetry. Consequently, the agency costs will be reduced. The agency theory has been recommended and applied in some prior ICD studies (e.g. [50]; [47]) by specifically focusing on the disclosure of IC information.

In the Islamic banks, in addition to the shareholders, there are other parties who are equally important, i.e. the depositors and investment account holders (IAHs) of the Islamic banks. Since these depositors provide capital to be managed by the Islamic bank, they can be seen to be similar to shareholders. Unlike depositors of conventional banks, who are deemed as creditors by the banks, the depositors of the Islamic banks are capital providers. This is 
because the depositor in an Islamic bank normally enters into a Mudharabah (partnership) contact, with the bank. Similarly, investment account holders provide funds to be invested by the Islamic bank. Therefore, the manager of an Islamic bank is not only responsible to shareholders but to the investment account holders and depositors as well.

\subsubsection{Islamic Accountability Theory}

The justification for this theory stems from the notion that the whole universe and all its embodiments belong to Allah (Qur'an Chapter 2:282; 42:4), and that man has been appointed by Allah to look after these $(33 ; 82)$ while the ultimate authority or dominion still rests with Allah. In addition, accountability encompasses all stakeholders, as conceived by the Shari'ah, and no individual stakeholder is more important than another, especially being reasonably considered. According to [64], accountability to Allah is through making information available. Truthful and relevant disclosure of information is important in different aspects of Islamic life. Full disclosure is necessary for predicting future obligations and assessing investment risk in Islamic partnership arrangements. Hence, the Islamic accounting theory would promote more IC information disclosure. Hypotheses Development of the Trend and Comparison of ICD

\subsection{Hypotheses Development of the Extent and Quality of ICD}

There are a number of ICD studies which have examined the extent of ICD in the annual reports and its trends (i.e. [8]; [23]; [65]). The findings of all the studies showed that there is an increase in the extent of ICD in the annual report over time. These findings indicate the possibility of increased awareness of the usefulness of IC and its components in terms of creating a company's value.

Based on the Islamic accountability theory, according to [47] there are two objectives to report in annual reports of Islamic banks which are firstly, to demonstrate accountability to God and community, and secondly, to increase transparency of business activities by providing relevant information to fulfil the spiritual needs of Muslim decision makers. Furthermore, the Islamic accountability theory requires a Muslim to continually improve over time. Thus, the IC information in annual report of Islamic banks could be disclosed and increased over time.

In addition, Islamic banking framework was developed over time, for example in the case of Malaysian Islamic banks, the Banking and Finance Institutions Act 1989, the Insurance Act 1996, the Payment Systems Act 2003, the Exchange Control Act 1953, the Islamic Banking Act 1983, and the Takaful Act 1984 were replaced by the Financial Services Act (FSA) and the Islamic Financial Services Act (IFSA) on $30^{\text {th } J u n e ~ 2013 . ~ T h i s ~ i s ~ l i n e ~ w i t h ~ t h e ~ a g e n c y ~}$ theory as well as Islamic accountability theory as these regulations would require better monitoring of Islamic banks including being more transparent. Hence, the IC information in the annual reports would increase over time. Therefore, based on the theories and discussion above, it is expected that there will be an increase (i.e. trend) in the disclosure of IC in the annual reports of Malaysian and Indonesian Islamic banks from 2009 to 2013. Thus, the following hypothesis is stated as:

H1: There is an increase in the ICD in the annual reports of Malaysian and Indonesian Islamic banks from 2009 to 2013. 


\subsection{Hypotheses Development of Categories of ICD}

The Islamic accountability theory suggests that transparency is important; which should apply to all categories of IC. In addition, the governance of Islamic banks should monitor the disclosure of all categories of IC equally as each category contributes to ICD. Therefore, all categories of IC should be of equal prominence and disclosed in the annual reports of Islamic banks. However, prior evidence indicates that the different categories do not seem to be given equal attention in terms of disclosure. Most studies show that external capital is the most disclosed category ([44]; [45] and [67]) because it is more about networking, customer relationships, and market presence. As demonstrated by previous studies, the disclosure levels are varied among the three categories. Therefore, based on these studies, the following hypothesis is stated as:

H2: There are differences in the level of disclosure among the three categories of IC (external, internal and human) in Malaysian and Indonesian Islamic banks in years 2009 to 2013.

Table 2. Percentage of ICD Based on Categories

\begin{tabular}{|c|c|c|c|}
\hline Country & $\begin{array}{c}\text { External } \\
\text { Capital }\end{array}$ & $\begin{array}{c}\text { Internal } \\
\text { Capital }\end{array}$ & $\begin{array}{l}\text { Human } \\
\text { Capital }\end{array}$ \\
\hline Australia & $40 \%$ & $30 \%$ & $30 \%$ \\
\hline Ireland & $40 \%$ & $30 \%$ & $30 \%$ \\
\hline South Africa & $40 \%$ & $30 \%$ & $30 \%$ \\
\hline Italy & $49 \%$ & $30 \%$ & $21 \%$ \\
\hline Sri Lanka & $44 \%$ & $20 \%$ & $36 \%$ \\
\hline United Kingdom & $60 \%$ & $26 \%$ & $14 \%$ \\
\hline $\begin{array}{l}\text { The Netherlands, Sweden and } \\
\text { United Kingdom }\end{array}$ & $40 \%$ & $30 \%$ & $30 \%$ \\
\hline Spain & $51 \%$ & $28 \%$ & $21 \%$ \\
\hline Portugal & $48 \%$ & $25 \%$ & $27 \%$ \\
\hline New Zealand & $36 \%$ & $11 \%$ & $53 \%$ \\
\hline Australia & $48 \%$ & $31 \%$ & $21 \%$ \\
\hline
\end{tabular}

\subsection{Hypothesis Development of Comparison of ICD between Malaysian and Indonesian Islamic Banks}

Indonesia and Malaysia aim to be International Islamic finance hub, hence the urgency for Islamic banks to rely not only on their own countries' resources, but to be able to attract international investors and other international alliances (e.g. a partnership alliance). Therefore, there should be more IC information in annual reports of Islamic banks. Improvement in disclosure indirectly reflects that the Islamic banks' encourage the alleviating of information asymmetry between the management and the stakeholders, including the shareholders, depositors and investment account holders.

In addition, Malaysian Islamic banks were established earlier than Indonesian Islamic banks. Therefore, more regulation and corporate governance requirements have been put in place in Malaysian Islamic banks for a longer time. Even though similar regulations exist in the Indonesian Islamic banks, they have been in place for a shorter time. More established regulations and requirements indicate stronger mechanisms to monitor and promote more ICD. For example, only minimum requirement is required by the Indonesian regulatory bodies (Capital Market) and Financial Institution Supervisory Agency/ BAPEPAM and LK and 
collaborates with the National Shari'ah Board Indonesia Ulama Council [67]. On the other hand, the requirements for the Malaysian Islamic banks have been refined and developed since 2006, to SGF in 2011 and further developed in 2013 under IFSA [68].Thus, ICD in these two countries is likely to be different as the extent of monitoring is unlikely to be the same. Therefore, based on the above reasons the following hypothesis is structured:

\section{H3: The ICD is significantly different between Malaysian and Indonesian Islamic banks. Hypotheses Development of the Determinants}

There are many elements of corporate governance which are SC, board of directors, board of committees, internal and external auditors and risk management. However, this study only focuses on SC, board of directors and audit committee. This is because these play key monitoring roles in an Islamic bank. The SC focuses on overseeing the Shari'ah compliance of all products and activities in the Islamic bank, including reporting. The board of directors are responsible for the operations and reporting in Islamic banks. Then, the audit committee oversees the audit of both internal and external auditors. The study develops five hypotheses for corporate governance attributes as determinants of ICD. These are: (1) number of SC; (2) experience on other SC (EOSC); (3) secular educational qualifications; (4) audit committee size; (5) board size. There are also three control variables, which are: (1) profitability (ROE); (2) firm size; and (3) leverage. These will be discussed in the following subsections.

\subsection{Number of SC}

An increase in the number of SC members may lead to higher levels of ICD as the capacity for monitoring increases. With regard to the minimum number of members of any $\mathrm{SC}$, in the case of Malaysian Islamic banks the minimum number is five members, as required by SGF, whereas in Indonesian Islamic banks, the minimum number is three, as required by Shari'ah supervisory or Dewan Shari'ah Nasional (DSN). This is a common requirement in many Islamic banks. The greater number in an SC, the more people to monitor, implying a greater level of compliance with Islamic laws and principles. The SC would be able to allocate its functions across a larger group of members, allowing the SC to review more aspects of the banks' activities and hence ensure greater compliance. One aspect of this compliance to the Shari'ah is to have full disclosure, hence more ICD voluntarily. Furthermore, synergies could be presented in boards with a large number of members pooling their ideas and perspectives to derive better applications of Islamic law, particularly with regard to disclosure.

[69] recommended a number of different people from different professionals to sit on SC, including bankers, economists and full-time member(s). This allows for the implementation of diverse perspectives on the application of the Shari'ah. To enable this to happen, a large SC would be required to represent these sectional professions. Thus, in line with the Islamic accountability theory, more SC members would enable better oversight on transparency as required by the Shari'ah.

In addition, agency theory can provide another explanation as the more number of SC members, would lead to more ICD due to better monitoring by more members. The theory suggests that the managers (principal) of the Islamic banks would be expected to disclose its activities, which include IC to shareholders and depositors, particularly if this information is deemed useful to these stakeholders. In providing more information, including in relations to IC, information asymmetry will be reduced. Therefore, based on the discussion above, the following hypothesis is developed:

H4: There is a significant positive association between numbers of SC members and ICD. 


\subsection{Experience on other SC (EOSC)}

Experience on other SC refers to a situation where a SC member has had experience as a SC member of another Islamic bank, in the past, or currently also sits on a SC of another Islamic bank. The former is more applicable to the context of Malaysia, whereas the latter is relevant to Indonesia. Having EOSC may also lead to higher disclosure of IC information [70].The literature mostly refers to cross-directorships, and it suggests that cross-directorship would increase transparency for two reasons: firstly, members with cross-directorships can make comparisons from knowledge gained in other companies; and secondly, "decisions at one board become part of the raw material for decisions at other boards" [22]. Similarly, EOSC enables the SC member to accumulate knowledge from their experiences in other banks. Therefore, this would result in better monitoring as proposed by the agency theory. Better monitoring means better fulfilment of responsibilities.

Islamic accountability theory can also provide another explanation; members with EOSC, having the knowledge, would be obligated to oversee that the Islamic banks are indeed transparent. Hence, the SC could encourage the Islamic banks to disclose more IC information in annual reports to promote transparency, accountability to God, and stakeholders. The above discussion suggests the following hypothesis:

H5: There is a significant positive association between the number of members with experience on other SC (EOSC) and ICD.

\subsection{Educational Qualification}

The educational qualification explains that the members of SC which have double major for example, the same person but he/she has graduated in different major (Shari'ah background and economic, finance or accounting). In the extant literature, the director's education has been proposed to influence the level of disclosure. On the other hand, in order to fully appreciate faithful representation in the annual reports, the SC members should be financially literate. Thus, they should have an accounting qualification or an educational background related to economics or finance. Similar to the case of EOSC, having a varied educational background, the SC members are more qualified and equipped to advise the banks. Thus, consistent with the agency theory, they are also able to monitor more effectively to ensure that these disclosure practices are applied, thus promoting transparency, including on ICD. In addition, the more qualified members of SC, they are expected to be more accountable and would insist on the Islamic banks disclosing more IC information. This is in line with the Islamic accountability theory. Therefore, based on discussion above, the hypothesis is structured as:

\section{H6: There is a significant positive association between the educational qualifications of SC members and ICD.}

\subsection{Audit Committee Size}

The role of the audit committee is to review the preparation of a company's financial statements, as well as the disclosure of value-relevant information such as intellectual capital information. This is line with the agency theory. A bigger audit committee is likely to be more effective in monitoring as it has more members from varied backgrounds to scrutinize over the reporting practices. Furthermore, [71] found that companies with a larger audit committee usually disclose more intellectual capital information in their annual reports. Therefore, based on the argument of better monitoring, the following hypothesis is framed: 


\section{H7: There is a significant positive association between audit committee size and ICD.}

\subsection{Boards of Directors}

Several studies ([23]; [53]; [72] and [73]) have specifically examined the association between ICD practices and board size and they found a positive relationship between them. In addition, [101] found that board size has a significant positive association with the extent of ICD in banks. Therefore, according to [23], [53],[72], [73] the larger board size would encourage a higher level of ICD in the Malaysian and Indonesian Islamic banking sector. Agency theory can support this hypothesis; the bigger the board size, the better the monitoring and overseeing of the reporting practices. Thus, the bigger the board size, the higher likelihood of better disclosure. This would reduce information asymmetry and agency costs. The following hypothesis is proposed:

H8: There is a significant positive association between board size and ICD.

Table 3. Research Framework (Research Objective, Research Question, Theory Applied and

\begin{tabular}{|c|c|c|c|}
\hline $\begin{array}{c}\text { RESEARCH } \\
\text { OBJECTIVE (RO) } \\
\end{array}$ & $\begin{array}{c}\text { RESEARCH } \\
\text { QUESTION (RQ) }\end{array}$ & $\begin{array}{l}\text { THEORY } \\
\text { APPLIED }\end{array}$ & $\begin{array}{l}\text { HYPOTHESIS } \\
\text { (Expectation) }\end{array}$ \\
\hline $\begin{array}{l}\text { RO. } 1 \\
\text { To examine the extent } \\
\text { and quality of ICD in the } \\
\text { annual reports of } \\
\text { Malaysian and } \\
\text { Indonesian Islamic banks } \\
\text { from the years } 2009 \text { to } \\
2013 \text {. }\end{array}$ & $\begin{array}{l}\text { RQ. 1 } \\
\text { What is the extent and } \\
\text { quality of ICDs in the } \\
\text { annual reports of } \\
\text { Malaysian and } \\
\text { Indonesian Islamic } \\
\text { banks from the years } \\
2009 \text { to 2013? }\end{array}$ & $\begin{array}{l}\text { Agency and } \\
\text { Islamic } \\
\text { Accountability }\end{array}$ & $\begin{array}{l}\text { H1 } \\
\text { There is an increase in the ICD in } \\
\text { the annual reports of Malaysian and } \\
\text { Indonesian Islamic banks from } 2009 \\
\text { to } 2013 \text {. }\end{array}$ \\
\hline $\begin{array}{l}\text { RO. } 2 \\
\text { To examine the } \\
\text { categories of ICD (extent } \\
\text { and quality) in both } \\
\text { Malaysian and } \\
\text { Indonesian Islamic banks } \\
\text { over time. }\end{array}$ & 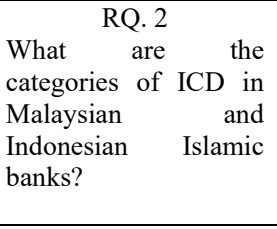 & $\begin{array}{l}\text { Islamic } \\
\text { Accountability }\end{array}$ & $\begin{array}{l}\mathrm{H} 2 \\
\text { There are differences in the level of } \\
\text { disclosure among the three } \\
\text { categories of IC (external, internal } \\
\text { and human) in Malaysian and } \\
\text { Indonesian Islamic banks in years } \\
2009 \text { to } 2013 \text {. }\end{array}$ \\
\hline $\begin{array}{l}\text { RO.3 } \\
\text { To compare between } \\
\text { ICD in annual reports of } \\
\text { Malaysian and } \\
\text { Indonesian Islamic banks } \\
\text { from 2009 until 2013 } \\
\end{array}$ & $\begin{array}{l}\text { RQ.3 } \\
\text { Is there a difference in } \\
\text { ICD of Malaysian and } \\
\text { Indonesian Islamic } \\
\text { banks? }\end{array}$ & - & $\begin{array}{l}\mathrm{H} 3 \\
\text { The ICD is significantly different } \\
\text { between Malaysian and Indonesian } \\
\text { Islamic banks. }\end{array}$ \\
\hline \begin{tabular}{l}
\multicolumn{2}{c}{ RO.4 } \\
To identify the \\
determinants of ICD in \\
the annual reports of \\
Malaysian rynd \\
Indonesian \\
banks.
\end{tabular} & $\begin{array}{l}\text { RQ.4 } \\
\text { What are the } \\
\text { determinants of ICD in } \\
\text { the annual reports of } \\
\text { Malaysian rand } \\
\text { Indonesian Islamic } \\
\text { banks? }\end{array}$ & $\begin{array}{l}\text { Agency and } \\
\text { Islamic } \\
\text { Accountability }\end{array}$ & $\begin{array}{l}\text { H4 } \\
\text { There is a significant positive } \\
\text { association between numbers of SC } \\
\text { members and ICD. } \\
\text { H5 } \\
\text { There is a significant positive } \\
\text { association between the number of } \\
\text { members with experience on other } \\
\text { SC (EOSC) and ICD. } \\
\text { H6 } \\
\text { There is a significant positive } \\
\text { association between the educational } \\
\text { qualifications of SC members and } \\
\text { ICD. } \\
\text { H7 } \\
\text { There is a significant positive }\end{array}$ \\
\hline
\end{tabular}




\begin{tabular}{|l|l|l|}
\hline & & $\begin{array}{l}\text { association between audit } \\
\text { committee size and ICD. } \\
\text { H8 }\end{array}$ \\
& Agency & $\begin{array}{l}\text { There a significant positive } \\
\text { association between board size and } \\
\text { ICD. }\end{array}$ \\
\hline
\end{tabular}

\section{Method}

\subsection{Research Design}

There are two types of research methods, which are qualitative and quantitative. This study focuses on the quantitative research method, using secondary data obtained from the annual reports of Malaysian and Indonesian Islamic banks. The population of Islamic banks is used in this study as the number of Islamic banks is limited in both countries. The study examines the extent and quality of ICD in the annual report of Malaysian and Indonesian Islamic banks within a five-year period, which is from 2009 until 2013. The second objective aims to examine the type (categories) on the extent and quality of ICD. In addition, the third objective is to compare ICD between Malaysia and Indonesia Islamic banks, and the last objective is to determine (number of SC, EOSC, educational qualifications, audit committee size and board size) the factor influencing of ICD in the annual report of Indonesian and Malaysian Islamic banks. Furthermore, the dependent variable is ICD, which is measured using a disclosure index, and the main independent variables are the number of SC, number of members with EOSC, number of SC educational qualifications, number of audit committees, and board size. In addition, there are three control variables, namely firm size, leverage and ROE.

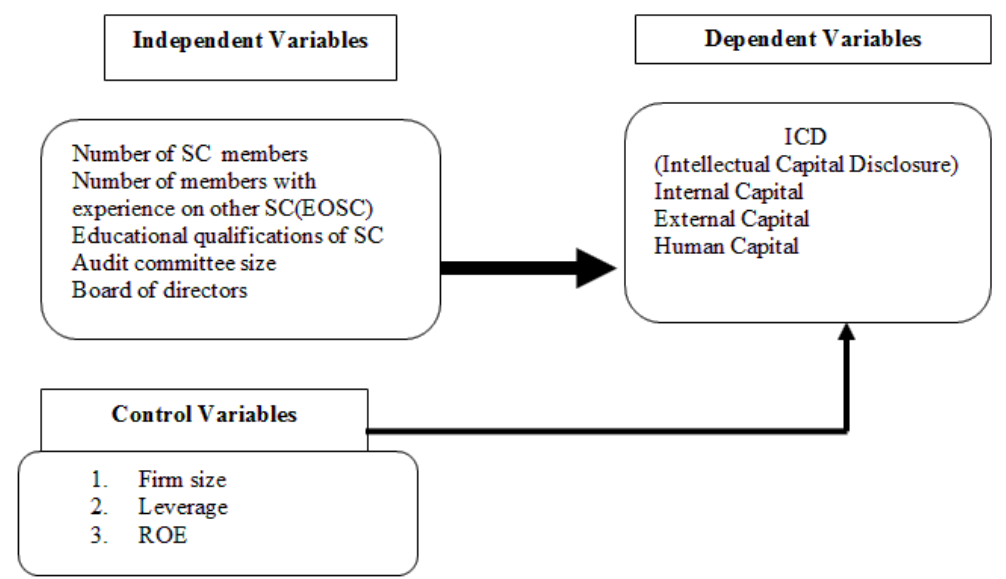

Fig.1. The Research Framework for Determinants of IC. 


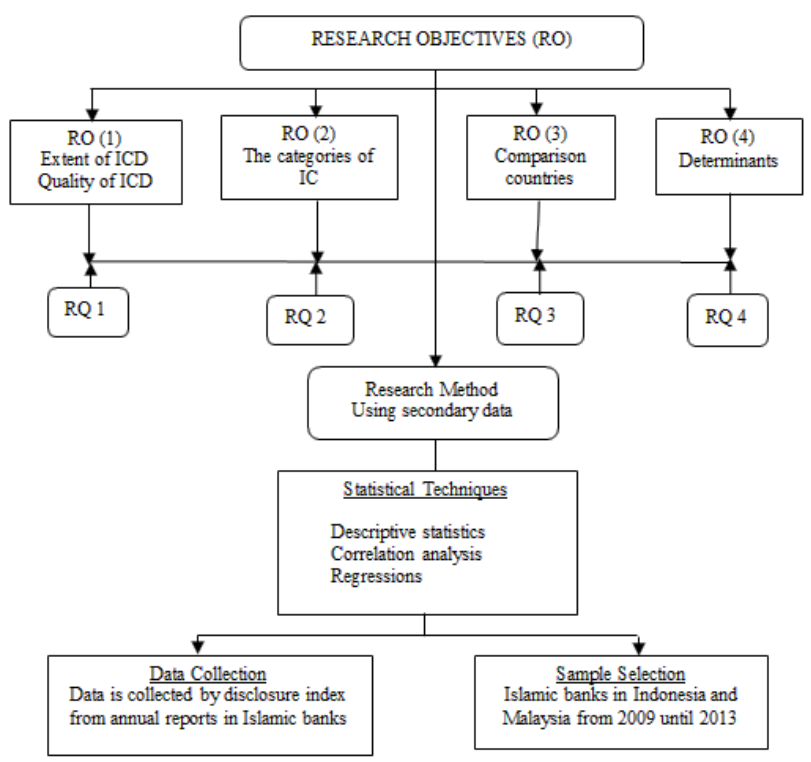

Fig.2. The Research Design

\subsection{Sample Selection}

This study focuses only on Islamic banks because the Islamic banking system has emerged as a competitive and viable substitute for the conventional banking system during the last three decades. Malaysia and Indonesia are selected because of the similarities in the basis of their Islamic banking systems, This study ignores other countries from South-East Asia such as Singapore, the Philippines and Thailand. This is because they are not majority Muslim countries, and each country has only one Islamic bank ([75]; [76], [78] [79], [78]). On the other hand, Brunei, a majority Muslim country, but it has only two Islamic banks [74]. The study uses quantitative research methods. The data is from annual reports, which are available on the websites of Islamic banks in Indonesia and Malaysia, covering five years, which are 2009, 2010, 2011, 2012 and 2013. 2013 is the latest and most recent data available at the time of data collection and also one of the objectives of this study is to look at the trend. Therefore, the study was begun from 2009 until 2013 to observe the trend of 5 years. In Malaysia, there are 16 Islamic banks, but only 15 Islamic banks are selected. There is one bank, which is not included, namely AmBank Islamic. The reason is that AmBank Islamic's annual reports are presented as a group. Indonesia has eleven fully-fledged Islamic banks. Therefore, the total number of annual reports combined from Malaysian and Indonesian Islamic banks is 122 annual reports.

Table 4. Sample of Selection of Indonesian and Malaysian Islamic Banks

\begin{tabular}{ccccccc}
\hline Countries & 2009 & 2010 & 2011 & 2012 & 2013 & $\begin{array}{c}\text { Total } \\
\text { Annual Reports }\end{array}$ \\
\hline Indonesian & 5 & 9 & 11 & 11 & 11 & 47 \\
Malaysian & 15 & 15 & 15 & 15 & 15 & 75 \\
\hline \multicolumn{7}{c}{ Overall annual reports } \\
\hline
\end{tabular}




\subsection{Variable Measurement}

Measurement of Independent Variables One of the objectives of this study is to determine the factors that influence disclosure of IC. Thus, the dependent variable of this study is ICD (i.e. extent and quality of disclosure). ICD is measured in totality, regardless of the items being voluntary. The disclosure index was developed based on a comprehensive review of prior ICD literature (e.g. [28], [29], [30], [31], [32], [34]). The ICD index consists 33 items in three categories: internal capital with nine items, external capital with eight items, and human capital with 16 items, as can be seen in attachment.

In scoring the IC index, some studies used a dichotomous approach (unweighted) where ' 0 ' was assigned for non-disclosure and a value of ' 1 ' was for a disclosed item ([80]; [81]; [82]). The foregoing discussion suggests that both approaches in measuring ICD have advantages and disadvantages. In order to host the advantages and tackle the disadvantages of each one, the current study adopts both approaches in measuring ICD. The dichotomous method measures the extent, while the weighting approach captures the quality of ICD. Therefore, the approach used in scoring the extent of the ICD is a dichotomous procedure whereby ' 0 ' is assigned if the items in the index do not appear in the annual report, and a value of ' 1 ' if the item is disclosed. Furthermore, many studies have been conducted on the quality of IC disclosure or reporting ([83], [44], [45]. [83]measured the quality of IC reporting using three types of quality measures, which are reporting theme (relative emphasis on each theme), form of disclosure (quantified or not), and location of disclosure. On the other hand, [45] and [45] identified forms of disclosure, which are monetary disclosure (score 3), numerical disclosure (score 2), and narrative disclosure (score 1).

There are various ways of measuring quality of disclosure [83]. [83] classified the measurement of quality of ICD into five forms, from 'Immaterial' to 'Quantitative'. However, a popular method is by [66]. The quality of the ICDs is captured in a weighting approach whereby a four-point scale (0-3) is used. A value of 0 was assigned if the item did not appear in the annual report; a value of 1 was assigned if the item appeared in narrative or discursive form; a value of 2 was assigned if the items were disclosed as numerical items; and the highest score of 3 was denoted if the items were disclosed monetarily (currency). This approach is used by this study as it is consistent with prior studies conducted by [28], [29], [30], [31], [32], [34]

\subsection{Measurement of Dependent Variables}

This study tests the determinants: if there is a significant relationship between ICD and the independent variables are number of SC, number of members with EOSC, educational qualifications of SC members, audit committee size, board directors and control variables are ROE, firm size, and leverage.

Table 4. Summary of the Source and Operationalisation of Independent Variables

\begin{tabular}{|c|c|c|c|c|}
\hline Hypothesis & $\begin{array}{l}\text { Independent } \\
\text { variables }\end{array}$ & Acronym & Operationalisation & $\begin{array}{c}\text { Source of } \\
\text { information }\end{array}$ \\
\hline \multicolumn{5}{|c|}{ Corporate governance (SC) } \\
\hline $\mathrm{H} 4$ & $\begin{array}{l}\text { Number of } \\
\text { SCs }\end{array}$ & NUM & Total number of SC members & $\begin{array}{l}\text { Bank annual } \\
\text { report }\end{array}$ \\
\hline H5 & $\begin{array}{l}\text { Number of } \\
\text { members with } \\
\text { EOSC }\end{array}$ & EOSC & $\begin{array}{l}\text { Total number of SC members } \\
\text { with experience on other SC }\end{array}$ & $\begin{array}{l}\text { Bank annual } \\
\text { report }\end{array}$ \\
\hline H6 & Educational & Education & Total number of SC members & Bank annual \\
\hline
\end{tabular}




\begin{tabular}{|c|c|c|c|c|}
\hline & $\begin{array}{l}\text { qualifications } \\
\text { of SC } \\
\text { member }\end{array}$ & & $\begin{array}{l}\text { which have a degree (formal } \\
\text { education) in economics, } \\
\text { finance or accounting }\end{array}$ & report \\
\hline $\mathrm{H} 7$ & $\begin{array}{l}\text { Audit } \\
\text { committee } \\
\text { size }\end{array}$ & ACSize & $\begin{array}{l}\text { Total number of directors on } \\
\text { the audit committee }\end{array}$ & $\begin{array}{l}\text { Bank annual } \\
\text { report }\end{array}$ \\
\hline H8 & $\begin{array}{l}\text { Board of } \\
\text { Directors }\end{array}$ & BSIZE & $\begin{array}{l}\text { Total number of board } \\
\text { directors sitting on the board }\end{array}$ & $\begin{array}{l}\text { Bank annual } \\
\text { report }\end{array}$ \\
\hline \multicolumn{5}{|c|}{ Control Variable } \\
\hline & Profitability & ROE & $\begin{array}{l}\text { Net profit after } \\
\text { tax/Shareholders' equity }\end{array}$ & $\begin{array}{l}\text { Bank annual } \\
\text { report }\end{array}$ \\
\hline & Firm size & SIZE & Total assets & $\begin{array}{l}\text { Bank annual } \\
\text { report }\end{array}$ \\
\hline & Leverage & LEV & Total debt to total assets & $\begin{array}{l}\text { Bank annual } \\
\text { report }\end{array}$ \\
\hline
\end{tabular}

\subsection{Statistical Techniques}

This study uses various statistical tests to analyse the data which include: descriptive statistics and correlation analysis (e.g. one-sample t-test, independent-samples t-test and oneway ANOVA), and multivariate test (i.e. OLS regression). A regression model is used to test the association between the dependent variable and the independent variables.

\subsubsection{Descriptive Statistics}

The descriptive statistics analyses are used to enable an overview of the sample [84]. For the purpose of this study, the specific descriptive analyses used central tendency (i.e. mean).

\subsubsection{Regression Model for Determinants}

The regression analysis is a statistical test used to explain and predict a dependent variable using data with more than one independent variable [84]. A multiple Ordinary Least Square (OLS) regression model based on the transformation of the continuous variables to normal score was adopted in this study to determine the relationship between the dependent and independent variables. In this study, based on the discussion above, the equation of the regression is specified as follows:

$\mathrm{ICD}=\alpha+\beta 1 \mathrm{SC}+\beta 2 \mathrm{EOSC}+\beta 3$ Education $+\beta 4 \mathrm{BSIZE}+\beta 5 \mathrm{ACSize}+\beta 6 \mathrm{SIZE}+\beta 7 \mathrm{LEV}+$ $\beta 8 \mathrm{ROE}+\mathrm{e}$

Where:

SC : Number of SC

EOSC : Number of members with experience on other SC

Education : Conventional education of SCs

ACsize : Number of audit committees

Bsize : Number of board directors

IND : Number of independent directors

Size : Firm size (total assets of the company)

LEV : Leverage (total liabilities to shareholders' equity)

ROE : Return on equity

$\beta \quad$ : Parameters to be estimated

$\alpha \quad$ : Regression intercept

e : Error 


\section{Results And Discussion}

\subsection{The Trend of ICD Results and Discussions}

The first objective of this study is to examine the extent of ICD in the annual reports of Indonesian and Malaysian Islamic banks in the years 2009 to 2013. Panel A presents the results of the extent of ICD, and Panel B presents the results of quality of ICD. As shown in Table there is a general increase in the overall ICD from 2009 to 2013 in both countries' Islamic banks. This finding is consistent with the findings of most prior ICD studies which conducted a trend analysis ([85]; [86]; [87]; [43]).

Specifically, the mean extent of ICD of Indonesian Islamic banks increased from 85.14 percent in 2009 to 92.57 percent in 2013 . However, from 2009 to 2010 it declined from 85.14 to 80.00 . The reason is that the sample used five Islamic banks in 2009, and in 2010 the number of Islamic banks increased to eight. In addition, the mean scores on the quality of ICD in Indonesian Islamic banks declined from 48.38 percent in 2009 to 42.43 percent in 2010, and then gradually increased to 48.76 percent in 2013 . The reason is that some of the Islamic banks are newcomers, thus the quality of disclosure may have brought down the average disclosure quality. However, in Malaysian Islamic banks, both extent and quality of ICD increased. The score for extent of ICD was 52.76 percent in 2009 and rose to 59.23 percent in 2013. The mean score for quality of ICD increased from 33.01 percent in 2009 to 37.71 percent in 2013 .

According to the data analysis, the mean percentages for extent of ICD are higher than the mean percentages of quality of ICD for the Islamic banks in both countries. This indicates that the disclosure is mainly qualitative in nature. These findings are consistent with prior observations in Malaysia [82] and elsewhere [44]. In addition, Table (Panel A) shows the trend of the extent of IC categories (i.e. internal capital, external capital, human capital). Table (Panel A) depicts that only the overall ICD and IC categories on human capital between 2011 and 2012 in Indonesian Islamic banks were weakly significant at the 0.1 significance level. This indicates that the extent of disclosure on human capital increased weakly significantly between 2011 and 2012. This increase has accumulated into a weakly significant increase in overall ICD in the same period. On the other hand, in Malaysia, the increase in the extent of overall ICD and its categories are gradual, except for the 'others' categories. Thus the increase is not significant.

Table (Panel B) shows that the paired sample t-test on the trend of the quality of ICD. It shows the results that the increase in the overall ICD and external capital in the years 20102011 and 2012-2013 in Indonesian Islamic banks were statistically significant. However in Malaysian Islamic banks, the internal capital in year 2012 - 2013 was statistically significant. In summary, the empirical results of the paired sample t-test (i.e. objective 1) supports Hypothesis H1 that the extent and quality of ICD (i.e. overall) in the annual reports of Malaysian and Indonesian Islamic banks had increased between the period 2009 and 2013. Indeed, the results are linked to Islamic accountability theory as increasing the transparency and improving the disclosure items over the years indicate that the banks are attempting to fulfil their obligation of accountability.Furthermore, agency theory is also supported due to the rapid improvement of ICD indirectly reflects the Islamic banks' reducing the information asymmetry between managers and shareholders. After discussing the trend of extent and quality of ICD in the annual reports of Malaysian and Indonesian Islamic banks, the following discussion will be continued with analyses of the extent and quality of ICD categories (i.e. Objective 2). 
Paired Sample T-Test of the Trend of the Extent and Quality of ICD: 2009-2013 in Malaysia and Indonesia Islamic Banks.

Table 5. PANEL A: EXTENT

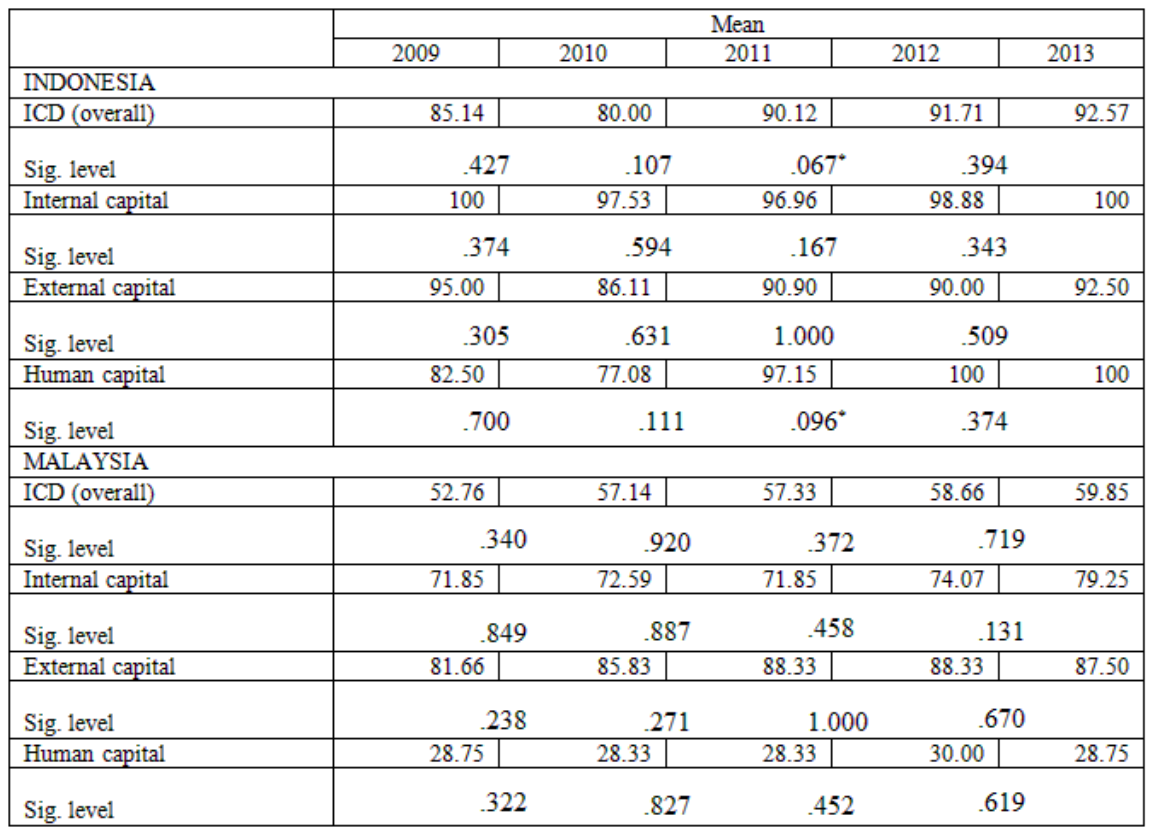

Table 6. PANEL B: QUALITY

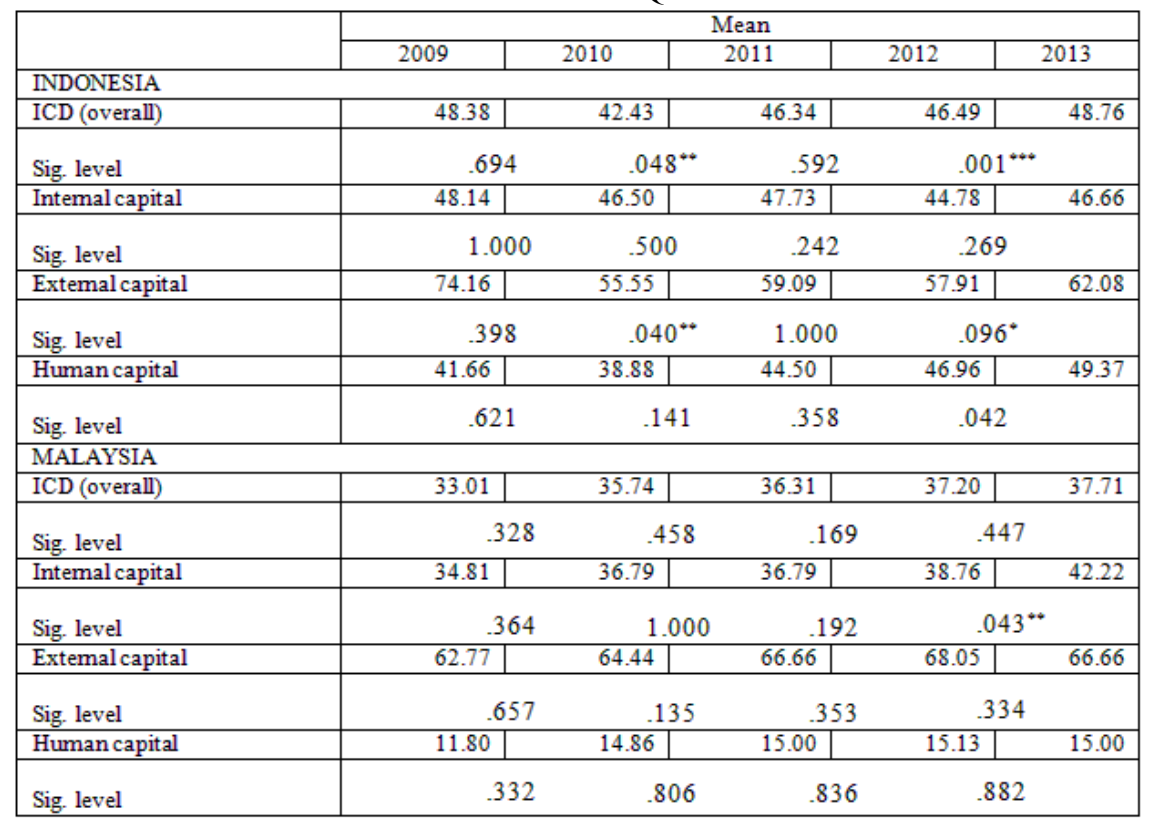


Note:
${ }_{* * *} \quad:$ Indicates significant at the 1 per cent level
${ }_{*}^{* *} \quad$ : Indicates significant at the 5 per cent level
$\quad$ Indicates significant at the 10 per cent level

\subsection{The Extent and Quality of ICD Results and Discussions}

The second objective of this study is to examine the type of disclosures (extent and quality) among IC categories in the annual reports of Malaysian and Indonesian Islamic banks between 2009 and 2013. It highlights the relevant results for easy comparison. The results presented in Table show that external capital was the highest disclosed in terms of the extent and quality of ICD between Malaysian and Indonesian Islamic banks from 2009 to 2013 . The findings of this study are in line with prior studies ([44], [45], [48], [81]). Their results also indicated that external capital was the highest compared to the two other IC categories.

External capital was the highest among the three IC categories in both Malaysian and Indonesian Islamic banks. The reason is that external capital is more about the relationship with depositors, market presence, networking, brands, licensing agreements or favourable contracts, and research collaboration. Therefore, Islamic banks would disclose more information about their resources which are the actual value for Islamic banks. The Islamic accountability theory is linked to hypothesis 2 because of the types of IC categories disclosed in annual reports of Malaysian and Indonesian Islamic banks as this theory suggests the managers should be transparent and accountable to stakeholders. The findings in relation to the second objective of this study support H2, which are the differences in the level of ICD among the categories of IC in the two countries (Malaysia and Indonesia). After examining the extent and quality of the categories of ICD (e.g. objective 2), the next section is a comparison of ICD between Malaysia and Indonesia.

Table 7. The Extent and Quality of ICD: 2009-2013 in Malaysian and Indonesian Islamic Banks

\begin{tabular}{lrrrrr}
\hline IC categories & \multicolumn{5}{c}{ Extent of ICD } \\
\cline { 2 - 6 } & \multicolumn{1}{c}{2009} & 2010 & 2011 & 2012 & \multicolumn{1}{c}{2013} \\
\hline INDONESIA & & & & & \\
Internal Capital & 100 & 97.53 & 96.96 & 98.98 & 100 \\
External Capital & 95.00 & 86.11 & 90.90 & 90.90 & 92.50 \\
Human Capital & 82.50 & 77.08 & 97.15 & 100 & 100 \\
MALAYSIA & & & & & \\
Internal Capital & 71.85 & 72.59 & 71.85 & 74.07 & 79.25 \\
External Capital & 81.66 & 85.83 & 88.33 & 88.33 & 85.50 \\
Human Capital & 21.66 & 28.75 & 28.33 & 30.00 & 28.75 \\
\hline
\end{tabular}

\begin{tabular}{lccccc}
\hline IC categories & \multicolumn{5}{c}{ Quality of ICD } \\
\cline { 2 - 6 } & 2009 & 2010 & 2011 & 2012 & 2013 \\
\hline INDONESIA & & & & & \\
Internal Capital & 48.14 & 46.50 & 46.46 & 44.78 & 46.66 \\
External Capital & 78.16 & 55.55 & 59.09 & 59.09 & 62.08 \\
Human Capital & 41.66 & 38.88 & 44.50 & 46.96 & 49.37 \\
MALAYSIA & & & & & \\
Internal Capital & 34.81 & 36.79 & 36.79 & 38.76 & 45.22 \\
External Capital & 62.77 & 64.44 & 66.66 & 68.05 & 66.66 \\
Human Capital & 11.80 & 14.86 & 15.00 & 15.13 & 15.00 \\
\hline
\end{tabular}




\subsection{The comparison of ICD between Malaysia and Indonesia Islamic banks}

The research objective 3 of this study is to compare the ICD in the annual reports of Islamic banks in Malaysia and Indonesia above indicates that in the five years, the Indonesian Islamic banks have a higher overall extent of ICD than the Malaysian Islamic banks. Similarly, the categories of IC are also higher for the Indonesian Islamic banks. The difference in the extent of overall ICD of the Indonesian and Malaysian Islamic banks was significantly different in the extent only in 2011 and 2012.

Table 8. Comparison of Malaysian and Indonesian Islamic Banks' Extent and Quality of ICD by Using Independent Sample T-test from 2009 to 2013

\begin{tabular}{lccccc}
\hline Overall of ICD & 2009 & 2010 & 2011 & 2012 & 2013 \\
\hline Difference in the extent (p-value) & .680 & .800 & .030 & .050 & 0.13 \\
Difference in the quality (p-value) & .950 & .530 & .500 & .430 & .360 \\
\hline
\end{tabular}

On the other hand, the quality of ICD in Indonesian Islamic banks is still higher than in Malaysian Islamic banks, but the difference is smaller. The quality of disclosure for the IC categories is also still higher in the Indonesian Islamic banks over the five years. The differences in the overall quality of ICD of Islamic banks in Indonesia and Malaysia are not significantly different over the five years. The hypothesis 3 was supported as the disclosure of IC information of Malaysian and Indonesian Islamic banks over five years between 2009 and 2013 were different. Therefore, since ICD in Malaysian and Indonesian Islamic banks are only of marginal difference, in general, the findings suggest that monitoring seems to be relatively similar. Therefore, the agency theory is applied in this hypothesis because the Islamic banks disclosed ICD in their annual reports in order to alleviate information asymmetry.

In addition, development of regulations and requirements of Islamic banks supported ICD in annual reports of Malaysian and Indonesian Islamic banks. After comparing the ICD of Malaysian and Indonesian Islamic banks, the following discussion will proceed with the determinants of ICD.

\subsection{The Determinants of ICD Results and Discussions}

The research objective 4 of this study is to examine the relationship between the dependent (i.e. extent ICD-Overall and Quality ICD-Overall) and independent variables (i.e. number of SC, number of member with EOSC, education of SCs' members, audit committee, board size, leverage, ROE, firm size). Table presents the correlation analysis of the extent and quality of ICD as well as the independent variables for the years 2009-2013 in Indonesian Islamic banks. The results show that there were no significant correlations between the independent variables. The highest correlation coefficient between the independent variables is 0.698 , which is lower than the value 0.80 [88].Thus, multicollinearity does not seem to be a problem amongst the independent variables.

Further analysis is regression analysis results of the determinants of the extent and quality of ICD, as shown in Table. The first model, which presents the relationship between the overall extent of ICD and independent variables, produces an adjusted r-square of 15 percent, suggesting that the independent variables included in this model can explain up to 15 percent of variation in the overall ICD practices. The results show that all variables are not significant in explaining the overall extent of ICD. However, the second model reports on the quality of ICD in Indonesian Islamic banks. This model shows an adjusted r-square of 42 percent. This indicates that the model is able to explain 63 percent of the association with the quality of ICD. 
Table in the model 2 , the results show that $\mathrm{SC}$ is marginally negatively significant at 10 percent, whereas board size (BSize), leverage (LEV), and return on equity (ROE) are all statistically positively significant at 1 percent, respectively. Therefore, hypothesis 4 is supported; the more number of SC members, the more ICD in Indonesia Islamic banks. Therefore, the findings seem to support both Islamic accountability and agency theories.

Hypothesis 8 is also supported as the bigger the board size, the more IC information is disclosed in annual reports of Indonesian Islamic banks. This finding supports agency theory as there seems to be more effective monitoring. Furthermore, there is a significant positive association between the quality of ICD and the number of boards of directors in Indonesian Islamic banks. The result shows that the greater number of directors in Islamic banks, the more disclosure of IC information. Hence, the result of this study is in line with prior observations as claimed by [23]. In addition, Table result of model 2 shows that the results of profitability (ROE) and leverage are found to be significant in terms of the quality of ICD in Indonesian Islamic banks. ROE is significant at the 1 percent level. The association between ROE and the quality of ICD is consistent with prior literature [89]). The significant relationship between leverage and quality of ICD in Indonesian Islamic banks is consistent with some previous ICD studies ([85], [46], [55]).

The agency theory explains positive relationships with leverage. Companies with higher leverage disclose more information to reduce agency costs. Thus, the positive sign in the results implies in this finding that Islamic banks with high leverage may disclose more information to signal to value creation potential to stakeholders. The result of leverage in this study, therefore, indicates that Indonesian Islamic banks with high leverage disclose more IC information in their annual reports, which is more supportive of agency theory.

On the other hand, Table shows the correlation analysis of extent and quality of ICD in Malaysian Islamic banks. The results show that there was no significant correlation between ICD and number of SC, number of members with EOSC, and education of SC' members. The highest correlation between the independent variables is 0.971 , which is higher than value 0.80 [84]. Among the variables that have high correlations are SC and cross-memberships, as well as the education of SCs. The highly correlated results suggest that larger SC have more financially literate members as well as more members with EOSC, which is logical. Thus, multicollinearity does seem to be a problem between the independent variables. Therefore, this study will have three models of regression separating these variables.

Table (Model 2) presents the relationship between the overall extent of ICD and the independent variables. The adjusted r-square is 13.6 percent. Under this model, number of members with EOSC is statistically positively significant at 10 percent level, with predicted direction (positive) as hypothesised in Malaysian Islamic banks. It indicates that more number of SC members with different experience can lead to higher ICD information. Hence, Hypothesis 5 is supported, but only for Malaysian Islamic banks to the extent of ICD. However, on the quality of ICD, shows that none of the variables are significant.

The findings support hypothesis 5; due to more members with EOSC, the higher the ICD in the annual reports of Malaysian Islamic banks. This is in line with both agency and Islamic accountability theories as with more members with EOSC, there seems to be better monitoring and discharging of accountability by having more disclosure. However, Table (Model 1) and Table (Model 3) report the results of determinants of extent and quality of ICD in Malaysian Islamic banks. None of the variables are significantly associated to ICD. 
Table 9. Correlation Analysis Results of the Variables on the Extent and Quality of Indonesian Islamic Banks for the Years 2009-2013

\begin{tabular}{|c|c|c|c|c|c|c|c|c|c|c|}
\hline & Extent & Quality & $\mathrm{Sc}$ & Eosc & Education & Acsize & Bsize & Lev & Roe & Size \\
\hline Extent/Quality & 1.000 & 1.000 & & & & & & & & \\
\hline $\mathrm{Sc}$ & 0.059 & 0.167 & 1.000 & & & & & & & \\
\hline Eosc & 0.286 & 0.098 & 0.671 & 1.000 & & & & & & \\
\hline Education & 0.289 & 0.198 & 0.469 & 0.698 & 1.000 & & & & & \\
\hline Acsize & -0.261 & -0.318 & 0.491 & 0.222 & 0.319 & 1.000 & & & & \\
\hline Bsize & 0.368 & 0.609 & 0.645 & 0.487 & 0.616 & 0.096 & 1.000 & & & \\
\hline Lev & -0.148 & -0.538 & -0.385 & -0.164 & -0.148 & 0.038 & -0.410 & 1.000 & & \\
\hline Roe & 0.296 & 0.407 & 0.446 & 0.557 & 0.058 & -0.193 & 0.328 & -0.293 & 1.000 & \\
\hline Size & -0.068 & -0.144 & -0.403 & -0.126 & 0.175 & -0.107 & -0.335 & -0.335 & -0.127 & 1.000 \\
\hline & Extent & Quality & $\mathrm{Sc}$ & Eosc & Education & Acsize & Bsize & Lev & Roe & Size \\
\hline Extent/Quality & 1.000 & 1.000 & & & & & & & & \\
\hline $\mathrm{Sc}$ & 0.059 & 0.167 & 1.000 & & & & & & & \\
\hline Eosc & 0.286 & 0.098 & 0.671 & 1.000 & & & & & & \\
\hline Education & 0.289 & 0.198 & 0.469 & 0.698 & 1.000 & & & & & \\
\hline Acsize & -0.261 & -0.318 & 0.491 & 0.222 & 0.319 & 1.000 & & & & \\
\hline Bsize & 0.368 & 0.609 & 0.645 & 0.487 & 0.616 & 0.096 & 1.000 & & & \\
\hline Lev & -0.148 & -0.538 & -0.385 & -0.164 & -0.148 & 0.038 & -0.410 & 1.000 & & \\
\hline Roe & 0.296 & 0.407 & 0.446 & 0.557 & 0.058 & -0.193 & 0.328 & -0.293 & 1.000 & \\
\hline Size & -0.068 & -0.144 & -0.403 & -0.126 & 0.175 & -0.107 & -0.335 & -0.335 & -0.127 & 1.000 \\
\hline
\end{tabular}

Table 10. Regression Analysis Results of the Determinants of Extent and Quality of ICD in Indonesian Islamic Banks

\begin{tabular}{lrrrr}
\hline \multirow{2}{*}{ Variables } & \multicolumn{2}{c}{ Overall ICDs (Extent) } & \multicolumn{2}{c}{ Overall ICDs (Quality) } \\
& \multicolumn{2}{c}{ Model 1 } & \multicolumn{2}{c}{ Model 2 } \\
\cline { 2 - 5 } & Coefficient & \multicolumn{1}{c}{ Sig. } & Coefficient & \multicolumn{1}{c}{ Sig. } \\
\hline SC & -4.034 & 0.174 & -7.137 & $0.0971^{*}$ \\
EOSC & 2.298 & 0.440 & -5.746 & 0.1839 \\
Education & 0.586 & 0.844 & 2.800 & 0.5159 \\
ACsize & -0.664 & 0.669 & -0.777 & 0.7280 \\
BSize & 1.735 & 0.123 & 5.933 & $0.0007^{* * *}$ \\
LEV & 0.068 & 0.738 & -0.247 & $0.0089^{* * *}$ \\
ROE & 0.068 & 0.467 & 0.375 & $0.0088^{* * *}$ \\
Size & -9.130 & 0.672 & -1.670 & 0.6353 \\
\hline R-squared & 0.321 & & 0.710 & \\
Adjusted R- & 0.151 & & 0.637 & \\
Squared & 1.894 & & 9.795 & \\
F. Statistic & 0.095 & & & \\
Prob (F-statistic) & & & & \\
\hline
\end{tabular}

Note:
: Indicates significant at the 1 per cent level
** $\quad$ : Indicates significant at the 5 per cent level
* : Indicates significant at the 10 per cent level
SC : Number of Shari'ah Committee
EOSC : Number of members with experience on other SC
Education : Conventional education of SCs
ACsize : Number of audit committees
Bsize : Number of board directors
IND : Number of independent directors
Size $\quad$ : Firm size (total assets of the company) 
LEV : Leverage (total liabilities to shareholders' equity)

ROE : Return on equity

Table 11. Correlation Analysis Results of the Variables on the Extent and Quality of Malaysian Islamic Banks for the Years 2009-2013

\begin{tabular}{|c|c|c|c|c|c|c|c|c|c|c|}
\hline & Extent & Quality & $\mathrm{Sc}$ & Eosc & Education & Acsize & Bsize & Lev & Roe & Size \\
\hline Extent/Quality & 1.000 & 1.000 & & & & & & & & \\
\hline $\mathrm{Sc}$ & 0.265 & 0.213 & 1.000 & & & & & & & \\
\hline Eosc & 0.348 & 0.273 & 0.971 & 1.000 & & & & & & \\
\hline Education & 0.270 & 0.246 & 0.860 & 0.879 & 1.000 & & & & & \\
\hline Acsize & 0.313 & 0.272 & 0.450 & 0.559 & 0.450 & 1.000 & & & & \\
\hline Bsize & 0.134 & 0.125 & 0.198 & 0.228 & 0.266 & 0.035 & 1.000 & & & \\
\hline Lev & -0.247 & -0.142 & 0.031 & 0.035 & 0.186 & -0.195 & 0.119 & 1.000 & & \\
\hline Roe & 0.128 & 0.020 & -0.147 & -0.174 & -0.318 & -0.081 & 0.046 & -0.647 & 1.000 & \\
\hline Size & -0.117 & -0.084 & -0.080 & -.0 .068 & -0.074 & -0.064 & 0.118 & 0.307 & -0.167 & 1.000 \\
\hline
\end{tabular}

Table 12. Regression Analysis Results of the Determinants of Extent and Quality of ICD in Malaysian Islamic Banks (Model 1)

\begin{tabular}{|c|c|c|c|c|}
\hline \multirow[t]{2}{*}{ Variables } & \multicolumn{2}{|c|}{ Overall ICDs (Extent) } & \multicolumn{2}{|c|}{ Overall ICDs (Quality) } \\
\hline & Coefficient & Sig. & Coefficient & Sig. \\
\hline $\mathrm{SC}$ & 0.667 & 0.2273 & 0.532 & 0.4798 \\
\hline ACsize & 0.413 & 0.2764 & 1.232 & 0.1709 \\
\hline BSize & -0.295 & 0.2261 & 0.550 & 0.2884 \\
\hline LEV & 0.018 & 0.8634 & -0.290 & 0.3884 \\
\hline ROE & -2.130 & 0.6655 & -0.055 & 0.7043 \\
\hline Size & 0.993 & 0.1321 & -3.000 & 0.6559 \\
\hline R-squared & 0.179 & & 0.112 & \\
\hline Adjusted R-Squared & 0.106 & & 0.033 & \\
\hline F. Statistic & 2.471 & & 1.429 & \\
\hline Prob (F-statistic) & 0.031 & & 0.216 & \\
\hline
\end{tabular}

Table 13. Regression Analysis Results of the Determinants of Extent and Quality of ICD in Malaysian

\begin{tabular}{|c|c|c|c|c|}
\hline \multirow[t]{2}{*}{ Variables } & \multicolumn{2}{|c|}{ Overall ICDs (Extent) } & \multicolumn{2}{|c|}{ Overall ICDs (Quality) } \\
\hline & Coefficient & Sig. & Coefficient & Sig. \\
\hline EOSC & 1.224 & $0.0538^{*}$ & 0.976 & 0.2693 \\
\hline Acsize & 0.587 & 0.3991 & 0.918 & 0.3406 \\
\hline Bsize & 0.317 & 0.3998 & 0.476 & 0.3605 \\
\hline LEV & -0.314 & 0.1915 & -0.305 & 0.3572 \\
\hline ROE & 0.027 & 0.7942 & -0.048 & 0.7391 \\
\hline Size & -1.620 & 0.7389 & -2.610 & 0.6971 \\
\hline R-squared & 0.206 & & 0.121 & \\
\hline Adjusted R-Squared & 0.136 & & 0.043 & \\
\hline F. Statistic & 2.941 & & 1.566 & \\
\hline Prob (F-statistic) & 0.013 & & 0.170 & \\
\hline
\end{tabular}


Table 14. Regression Analysis Results of the Determinants of Extent and Quality of ICD in Malaysian Islamic Banks (Model 3)

\begin{tabular}{|c|c|c|c|c|}
\hline \multirow[t]{2}{*}{ Variables } & \multicolumn{2}{|c|}{ Overall ICDs (Extent) } & \multicolumn{2}{|c|}{ Overall ICDs (Quality) } \\
\hline & Coefficient & Sig. & Coefficient & Sig. \\
\hline Education & 1.092 & 0.1044 & 1.048 & 0.2532 \\
\hline Acsize & 0.837 & 0.2071 & 1.026 & 0.2582 \\
\hline Bsize & 0.309 & 0.4237 & 0.434 & 0.4124 \\
\hline $\mathrm{LEV}$ & -0.328 & 0.1777 & -0.325 & 0.3288 \\
\hline ROE & 0.045 & 0.6778 & -0.028 & 0.8484 \\
\hline Size & -1.220 & 0.8048 & -2.000 & 0.7687 \\
\hline R-squared & 0.193 & & 0.212 & \\
\hline Adjusted R-Squared & 0.122 & & 0.045 & \\
\hline F. Statistic & 2.714 & & 1.583 & \\
\hline Prob (F-statistic) & 0.020 & & 0.165 & \\
\hline
\end{tabular}

Note:

: Indicates significant at the 1 per cent level

** $\quad:$ Indicates significant at the 5 per cent level

* $\quad$ : Indicates significant at the 10 per cent level

SC : Number of Shari'ah Committee

EOSC : Number of members with experience on other SC

Education : Conventional education of SCs

ACsize : Number of audit committees

Bsize : Number of board directors

IND : Number of independent directors

Size $\quad$ : Firm size (total assets of the company)

LEV : Leverage (total liabilities to shareholders' equity)

ROE : Return on equity

Table 15. Summary of Hypothesis Testing and Results of Regression Models of the Determinants of the

\begin{tabular}{|c|c|c|c|c|c|}
\hline \multirow[t]{2}{*}{ Variable } & \multirow{2}{*}{$\begin{array}{l}\text { Hypothesis } \\
\text { Tested }\end{array}$} & \multirow{2}{*}{$\begin{array}{c}\text { Expected } \\
\text { Sign } \\
\end{array}$} & \multicolumn{2}{|c|}{ Results } & \multirow{2}{*}{$\begin{array}{l}\text { Hypothesis } \\
\text { Support }\end{array}$} \\
\hline & & & Sig. & Sig. & \\
\hline \multirow[t]{4}{*}{$\mathrm{SC}$} & $\mathrm{H} 4$ & & & & \\
\hline & $\begin{array}{l}\text { There is a significant positive } \\
\text { association between numbers of SC } \\
\text { members and ICD }\end{array}$ & & & & \\
\hline & Malaysia & + & - & No & Not Supported \\
\hline & Indonesia & + & - & No & Not Supported \\
\hline \multirow[t]{4}{*}{ EOSC } & H5 & & & & \\
\hline & $\begin{array}{l}\text { There is a significant positive } \\
\text { association between the number of } \\
\text { members with experience on other SC } \\
\text { (EOSC) and ICD. }\end{array}$ & & & & \\
\hline & Malaysia & + & + & Yes & Supported \\
\hline & Indonesia & + & - & No & Not Supported \\
\hline \multirow[t]{2}{*}{ Education } & H6 & & & & \\
\hline & $\begin{array}{l}\text { There is a significant positive } \\
\text { association between the educational } \\
\text { qualifications of SC members and ICD }\end{array}$ & & & & \\
\hline
\end{tabular}




\begin{tabular}{|c|c|c|c|c|c|}
\hline \multirow{5}{*}{ ACsize } & Malaysia & + & - & No & Not Supported \\
\hline & Indonesia & + & - & No & Not Supported \\
\hline & $\mathrm{H} 7$ & & & & \\
\hline & There is a significant positive & & & & \\
\hline & $\begin{array}{l}\text { association between audit committee } \\
\text { size and ICD }\end{array}$ & & & & \\
\hline \multirow{6}{*}{ Bsize } & Malaysia & + & - & No & Not Supported \\
\hline & Indonesia & + & - & No & Not Supported \\
\hline & & & & & \\
\hline & $\begin{array}{l}\text { There is a significant positive } \\
\text { association between board size and } \\
\text { ICD. }\end{array}$ & & & & \\
\hline & Malaysia & + & - & No & Not Supported \\
\hline & Indonesia & + & - & No & Not Supported \\
\hline
\end{tabular}

Table 16. Summary of Hypothesis Testing and Results of Regression Models of the Determinants of the Quality of ICD 


\begin{tabular}{|c|c|c|c|c|c|}
\hline \multirow[t]{2}{*}{ Variable } & \multirow{2}{*}{$\begin{array}{l}\text { Hypothesis } \\
\text { Tested }\end{array}$} & \multirow{2}{*}{$\begin{array}{c}\text { Expected } \\
\text { Sign } \\
\end{array}$} & \multicolumn{2}{|c|}{ Results } & \multirow{2}{*}{$\begin{array}{l}\text { Hypothesis } \\
\text { Support }\end{array}$} \\
\hline & & & Sig & Sig. & \\
\hline \multirow[t]{4}{*}{$\mathrm{SC}$} & $\mathrm{H} 4$ & & & & \\
\hline & $\begin{array}{l}\text { There is a significant positive } \\
\text { association between numbers of SC } \\
\text { members and ICD }\end{array}$ & & & & \\
\hline & Malaysia & + & - & No & Not Supported \\
\hline & Indonesia & + & - & YES & Supported \\
\hline \multirow[t]{3}{*}{ EOSC } & $\begin{array}{l}\text { H5 } \\
\text { There is a significant positive } \\
\text { association between the number of } \\
\text { members with experience on other SC } \\
\text { (EOSC) and ICD. }\end{array}$ & & & & \\
\hline & Malaysia & + & - & No & Not Supported \\
\hline & Indonesia & + & - & No & Not Supported \\
\hline \multirow[t]{3}{*}{ Education } & $\begin{array}{l}\text { H6 } \\
\text { There is a significant positive } \\
\text { association between the educational } \\
\text { qualifications of SC members and ICD }\end{array}$ & & & & \\
\hline & Malaysia & + & - & No & Not Supported \\
\hline & Indonesia & + & - & No & Not Supported \\
\hline \multirow[t]{3}{*}{ ACsize } & $\begin{array}{l}\text { H7 } \\
\text { There is a significant positive } \\
\text { association between audit committee } \\
\text { size and ICD }\end{array}$ & & & & \\
\hline & Malaysia & + & - & No & Not Supported \\
\hline & Indonesia & + & - & No & Not Supported \\
\hline \multirow[t]{4}{*}{ Bsize } & H8 & & & & \\
\hline & $\begin{array}{l}\text { There is a significant positive } \\
\text { association between board size and } \\
\text { ICD. }\end{array}$ & & & & \\
\hline & Malaysia & + & - & No & Not Supported \\
\hline & Indonesia & + & + & Yes & Supported \\
\hline
\end{tabular}

\section{Conclusion}

\subsection{The Summary of The Study and Findings}

The current study focuses on the disclosure of IC information and has several objectives. Firstly, the study examines the trend of extent and quality of ICD in the annual reports of Malaysian and Indonesian Islamic banks from 2009 until 2013. Secondly, it aims to examine the differences in the types (categories) of ICD (extent and quality) in both Malaysian and Indonesian Islamic banks over time. Thirdly,this study also focused on comparison of ICD between Malaysia and Indonesia in annual reports of Islamic banks within five years.Fourthly, the study examines the determinants factors influencing the ICD in Malaysian and Indonesian Islamic banks. 
The data of this study is based on secondary data collected from eleven Islamic banks in Indonesia and 15 Islamic banks in Malaysia. The study used 33 items of IC index to measure the extent and quality of ICD. This study has employed several statistical techniques which include descriptive statistics, correlations analysis, one sample t-test and independent sample t-test.

Specifically, to meet the first objective, this study used a paired sample t-test. The results depict that there is an increasing trend towards extent and quality of ICD and its categories from 2009 to 2013 in Malaysian and Indonesian Islamic banks. The second objective has also used the same test as used in the first objective. The study found that the external capital has the highest disclosure in terms of extent and quality of ICD in Islamic banks of both countries. Furthermore, the third objective used independent sample t-test to analyse the comparison of the extent and quality of ICD between Malaysian and Indonesian Islamic banks. The result found that Indonesian Islamic banks have a higher ICD compared to Malaysian Islamic banks. Finally, the fourth objective of this study is to analyse data using multiple ordinary least square regression model. Based on the regression results of the determinants, the empirical results support the hypothesis that the extent of ICD in the annual reports of Malaysian Islamic banks is influenced by EOSC.

On the other hand, the quality of ICD in Indonesian Islamic banks has is positively affected by SC, board size, leverage and ROE. Table below summarises the number of research objectives, research questions, hypotheses and findings obtained from this study.

Table 17. Research Objectives, Research Questions, Hypotheses, and Findings of the Study

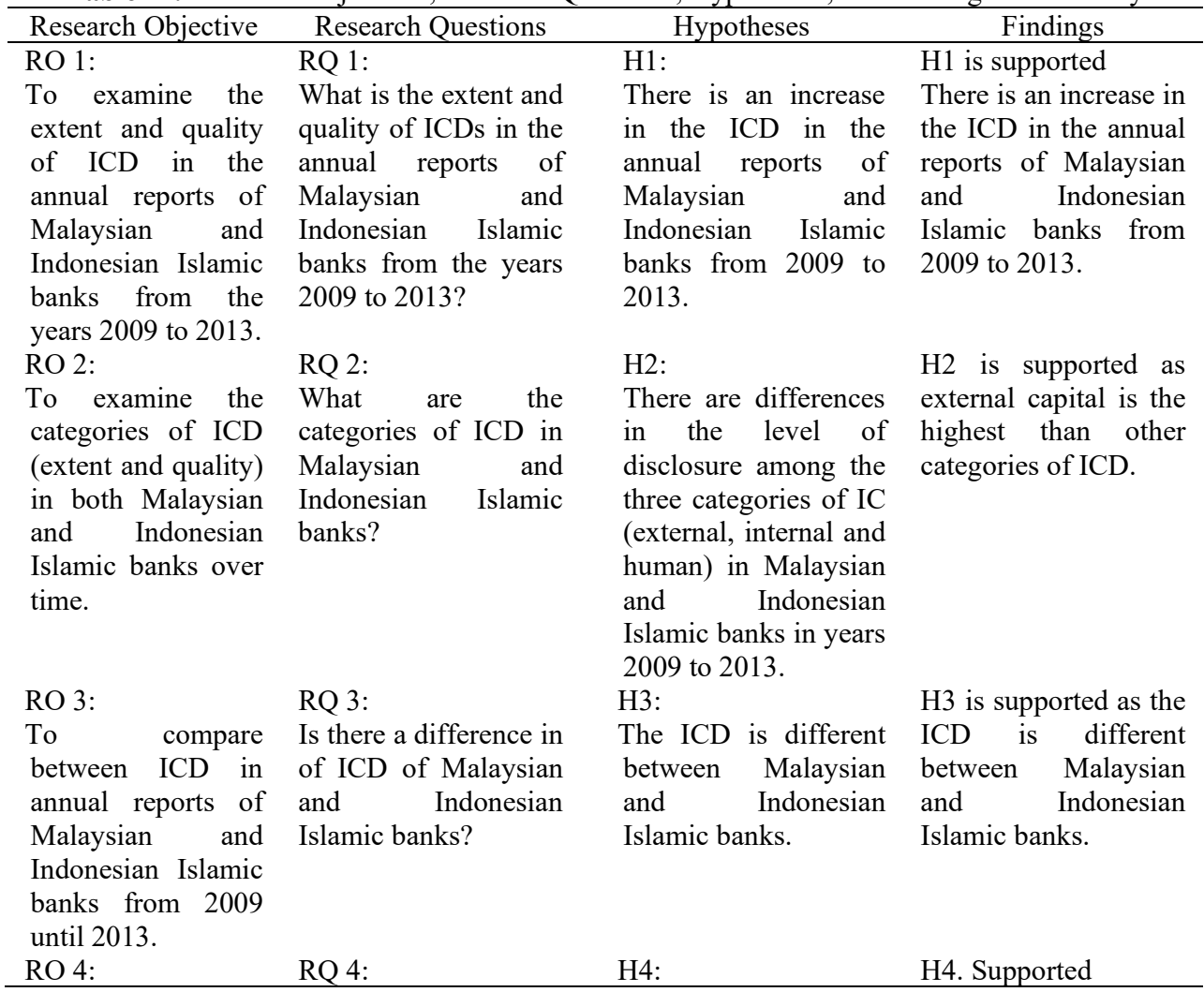




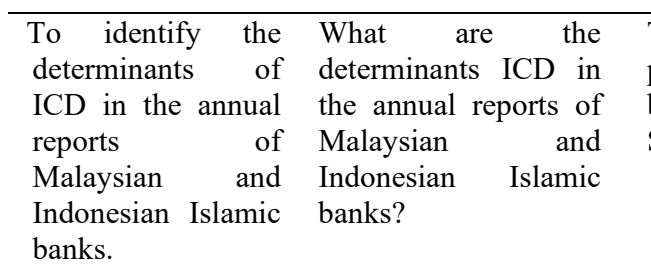

$$
\text { H5: }
$$

There is a significant positive association between the number of members with experience on other SC (EOSC) and ICD.

H6:

There is a significant positive association between the educational qualifications of $\mathrm{SC}$ members and ICD.

H7:

There is a significant positive association between audit committee size and ICD.

H8:

There is a significant positive association between board size and ICD.
There is a significant positive association between numbers of $\mathrm{SC}$ members and the quality of ICD in Indonesian Islamic banks.

H5. Supported There is a significant positive association between the number of members with EOSC and the extent of ICD in Malaysian Islamic banks.

H6. Rejected.

H7. Rejected.

H8. Supported.

There is a significant positive association between board size and the quality of ICD in Indonesia Islamic banks

\subsection{Implication for Theory}

The empirical evidence of this study shows the applicability of both agency and Islamic accountability theories. The Malaysian and Indonesian Islamic banks disclosed their IC information in their annual report over the five years. The more SC members in Islamic banks, the more IC information will be disclosed in the annual reports. These findings are only applicable in Indonesian Islamic banks. On the other hand, the more members with EOSC, the more ICD in the annual reports of Islamic banks, but it only applies to Malaysian Islamic banks' context. Therefore, agency theory and Islamic accountability theory only apply to specific contexts of ICD practices of Islamic banks in Malaysia and Indonesia.

In addition, the more board of director members, the more ICD in the annual reports of Islamic banks in Indonesia. Thus, agency theory applies in this study to the case of Indonesian 
Islamic banks but it does not apply in Malaysian Islamic banks' context. However, the results of two independent variables do not seem to support these theories (education and qualification of SC members and audit committee). Possibly these variables could be tested in the context of other theories in future research.

\subsection{Implication for Stakeholders, Regulators and Practitioners}

The empirical findings of this study have several implications which may be useful to various parties. Firstly, the study found that ICD increases in Indonesian and Malaysian Islamic banks from 2009 to 2013. Therefore, stakeholders could get IC information in annual reports of Islamic banks and it may be beneficial for them to invest their money in banks with higher ICD. Secondly, this study presents that external capital is higher than other IC categories in Islamic banks of both countries (Malaysia and Indonesia). External capital is more about customer relationship, market presence, networking, brands, business collaboration, licensing agreements and research collaboration. Thus, Islamic banks disclosed more of that item. However, external capital should be supported by other categories of IC capital, particularly human capital. This is because human capital, along with SC, is crucial in the development of Shari'ah-compliant yet competitive financial products in Islamic banks. Therefore, this has to be relayed to stakeholders through proper disclosure.

Indonesian Islamic banks disclosed more ICD compared to Malaysian Islamic banks. This is quite a surprising finding, as Islamic banks in Malaysia seem to be older and more established. However, it must be noted that there are only two fully-fledged Islamic banks in Malaysia compared to the ten in Indonesia. Upon further analysis, the fully-fledged Islamic banks seem to disclose more IC information compared to the subsidiaries and foreign Islamic banks. Regulation should take these findings into consideration, particularly since they could have an effect on attracting investors, especially since both Malaysia and Indonesia aim to be Islamic financial hubs.

Furthermore, this study found that number of members with EOSC has a significant relationship on the extent of ICD in Malaysian Islamic banks, whereas SC and board size is positively significant in the case of Indonesia. These findings suggest that the larger the SC, board and the more SC members with EOSC, the more effective the monitoring in Islamic banks in Indonesia and Malaysia, respectively. Hence, the higher the ICD, based on the findings, the more stakeholders and depositors of these banks may prefer banks with larger boards or more SC cross-memberships, respectively.

\subsection{Implication for Researcher}

This study provides essential implications to the body of knowledge, specifically the accounting field. Therefore, the study should be extended and modified in various ways. Evidence derived from this study suggests that both countries Malaysian and Indonesian Islamic banks have IC information in their annual reports, which has been increasing over the 5 years. In addition, the study adopts new variables to test relationship between ICD and SC, EOSC, and education qualification of SC. Therefore, this study has filled certain gaps in the literature suggestions on the ICD. The next section provides the possible ways to extend this literature by future researches. These suggestions will be discussed after the limitation of this study is highlighted.

Although the current study has provided some contributions, it is not void of limitations. There are some limitations of this study, which are firstly that the sample selection is only two countries (Malaysia and Indonesia) over five years (2009, 2010, 2011, 2012 and 2013). Future 
research should focus on more countries, or majority Islamic countries and different years. In addition, the second limitation is that the study presents quantitative results which are only obtained from annual reports of Islamic banks. Future research could consider both qualitative and quantitative research.

In addition, five independent variables are considered in this study. These variables were selected due to their relevance based on prior studies. Future research could incorporate more independent variables in order to explore other variables that may influence the disclosure of IC in the annual reports of Islamic banks. Regardless of the limitations, it is hoped that this study would assist companies as well as regulators to further enhance ICD practices, particularly in Islamic banks towards greater transparency, as there are clear benefits.

\section{References}

[1] Soedaryono, B., Murtanto and Prihartini, A. (2012). Effect intellectual capital (Value Added Intellectual Capital) to market value and financial performance of banking sector companies listed in Indonesia stock exchange. In 2 International Conference on Business and Management. 89-106.

[2] Steward, T., A. (1997). Intellectual Capital: The New Wealth of Organizations (1st Edition. New York: Doubleday/ Currency.

[3] Khan H. and Ali M., (2010). An empirical investigation and users perceptions on intellectual capital reporting in banks: evidence from Bangladesh. Journal of Human Resource Costing and Accounting, 14 (1), 48- 69.

[4] Bontis, N., Keow, W. C., and Richardson, S. (2000). Intellectual capital and business performance in Malaysian industries. Journal of Intellectual Capital, 1(1), 85-100.

[5] Pablos, P. O. (2002). Evidence of intellectual capital measurement from Asia, Europe and the Middle East. Journal of Intellectual Capital, 3(3), 287-302.

[6] Pablos, P. O. (2003b). Intellectual capital reporting in Spain: a comparative view. Journal of Intellectual Capital, 4(1), 61-81.

[7] Ismail, M.B., (2005). The Influence of intellectual capital on the performance of telekom Malaysia. PhD Thesis: Universiti Teknologi Malaysia.

[8] Goh, P. C. (2005). Intellectual capital performance of commercial banks in Malaysia. Journal of Intellectual Capital, 6(3), 385-396.

[9] De Castro, G. M., and Sáez, P. L. (2008). Intellectual capital in high-tech firms: The case of Spain. Journal of Intellectual Capital, 9(1), 25-36.

[10] Khalique, M. (2012). Impact of intellectual capital on the organizational performance of selected small and medium enterprises in Malaysia and Pakistan PhD Thesis, Universiti Malaysia Sarawak.

[11] Khalique, M., Shaari, J. A. N., Isa, A. H. B. M., and Alkali, M. (2012). Intellectual capital and banking sector of Pakistan. International Journal of Research in Commerce, Economics \& Management, 2(6), 1-5.

[12] Sharabati, A. A. A., Jawad, S. N., and Bontis, N. (2010). Intellectual capital and business performance in the pharmaceutical sector of Jordan. Management Decision, 48(1), 40-65.

[13] Saleh, S., and Gan, K. (2008). Intellectual capital and corporate performance of technologyintensive companies: Malaysia evidence. Asian Journal of Business and Accounting, 8 (1), 113-130.

[14] Sveiby K. E. (1997). The new organizational wealth: Managing and measuring knowledge base assets. San Francisco, CA: Berret-Koehler.

[15] Bontis, N., Keow, W. C. C., and Richardson, S. (2000). Intellectual capital and business performance in Malaysian industries. Journal of Intellectual Capital, 1, 85-100.

[16] Live Trading News. (2012). "Asia aim to be Islamic Finance Hub" available at: www.islamicfinance-conference-net/2012/09/asia-aims-to-be-islamic-finance-hub-html (accessed 6 December 2012) 
[17] Schmit, S. (2007). Islamic banking experiencing rapid growth. Retrieved February, 10, 2012, from http:/www.ita.doc.gov/td/finance/publications/Islamic_Banking.pdf.

[18] Cooper, D. R., and Schindler, P. S. (2009). Business research methods (tenth edition). New York: Mc Graw Hill.

[19] Darmadi, S. (2013). Corporate governance disclosure in the annual report "An exploratory study on Indonesian Islamic Banks". Humanomics, 29 (1), 4-23.

[20] Haniffa, R and Hudaib, M.A. (2002). A theoretical framework for the development of the Islamic perspective of accounting, accounting, commerce and finance. The Islamic Perspective Journal, $6(1 / 2), 1-71$.

[21] Haniffa, R and Hudaib, M, A. (2007). Exploring the ethical identity of Islamic bank via communication in annual reports, Journal of Business Ethics, 76, 97-116.

[22] Harahap, S.S. (2003). The disclosure of Islamic value annual reports. the analysis of bank Muamalat Indonesia's annual report. Managerial Finance, 29 (7). 70-89.

[23] Ahmed Haji, A and Mubaraq, S. (2013). The impact of corporate governance attributes of intellectual capital disclosure: A longitudinal investigation of Nigerian banking sector. Journal of Banking Regulation, 16(3), 184-209.

[24] Farook, S., Hasan, M. K, and Lanis, R. (2011). Determinants of corporate social responsibility disclosure: case of islamic bank. Journal of Islamic Accounting and Business Research, 2(2). 114141.

[25] Brooking A. (1996). Intellectual capital, core assets for the third millennium enterprise. London: International Thomson Business Press.

[26] Beaulieu, P.R., Williams, S. M., and Wright, M.E. (2002). Intellectual capital disclosures in Swedish annual reports. In N. Bontis (eds), World Congress on Intellectual Capital Reading (pp.135-156). Boston: Butterworth-Heinemann.

[27] Bontis, N., Dragonetti, N. C., Jocobsen, K,. and Roos, G. (1999). The knowledge toolbox: a review of the tools available to measure and manage intangible resources. European Management Journal, 17(4), 391-420.

[28] Kaplan, R.S., and Norton, D.P. (1992). The balanced scorecard - measurement that drive performance. Harvard Business Review, 70(1). 71-79.

[29] Petrash, G. (1996). Dow's journey to a knowledge value management culture. European Management Journal, 14(4). 365-373

[30] Sveiby K. E. (1997). The new organizational wealth: Managing and measuring knowledge base assets. San Francisco, CA: Berret-Koehler.

[31] Edvinsson, L. and Malone, M.S. (1997). Intellectual Capital. Judy Piatkus, London

[32] Roos, J., Roos, G., Dragonetti, N. C., and Edvinsson, L. (1997). Intellectual Capital: Navigating in the New Business Landscape. Houndmills: Macmillan Business.

[33] Pulic, A. (1998, June). Measuring the performance of intellectual capital potential in knowledge economy. paper presented at the $2^{\text {nd }}$ McMaster World congress on measuring and managing intellectual capital by the Austrian Team for intellectual potential. Retrieved March 8, 2009. http://www.measuring-p.at/Opaperts/public/Vaictxt.vaictxt.html.

[34] Bontis, N. (2003). Intellectual capital disclosure in Canadian corporations. Journal of Human Resource Costing \& Accounting, 7, 9-20.

[35] Chen, J., Zhu, Z., and Xie, H.Y.(2004). Measuring intellectual capital: a new model and empirical study. Journal of Intellectual Capital, 5 (1), 195-212.

[36] Pike, S., and Roos, G. (2004). Mathematics and modern business management. Journal of Intellectual Capital, 5(2), 243-256.

[37] Marr, B., Schiuma, G., and Neely, A. (2004). Intellectual capital-defining key performance indicators for organizational knowledge assets. Business Process Management Journal, 10(5), 551569.

[38] Sveiby, K.E. (2007). Methods for measuring intangible assets. Retrieved March 8, 2009. http://www.sveiby.com/portals/0/articles/intangiblemethods.htm

[39] Tan, H. P., Plowman, D., and Handcock, P. (2007). Intellectual capital and financial returns of companies. Journal of Intellectual Capital, 8(1), 76-95 
[40] Mohiuddin, M., Najibullah, S., and Shahid, A.I. (2006). An exploratory study on intellectual capital performance and the commercial banks in Bangladesh. The Cost and Manaagement, 34 (6), 40-54.

[41] Firer, S., and Williams, S. (2003). Intellectual capital and traditional measures of corporate performance, Journal of Intellectual Capital, 4(3), 348-360.

[42] Rodov, I., and Leliaret, P. (2002). FiMIAM: financial method of intangible assets measurement. Journal of Intellectual Capital, 3(3), 323-336.

[43] Vandemaele, S. N., Vergauwen, P. G. M. C., and Smits, A. J. (2005). Intellectual capital disclosure in The Netherlands, Sweden and the UK: A longitudinal and comparative study. Journal of Intellectual Capital, 6(3), 417-426.

[44] Abeysekera, I., and Guthrie, J. (2005). An empirical investigation of annual reporting trends of intellectual capital in Sri Lanka. Critical Perspectives on Accounting 16, 151-163.

[45] Bozzolan, S., Favotto, F., and Ricceri, F. (2003). Italian annual intellectual capital disclosure: An empirical analysis. Journal of Intellectual Capital, 4(4), 543-55

[46] White, G., Lee, A., and Tower, G. (2007). Drivers of voluntary intellectual capital disclosure in listed biotechnology companies. Journal of Intellectual Capital, 8(3), 517-537.

[47] Jing L., Pike, R., and Hanifa, R. (2006). Intellectual capital disclosure in corporate annual reports: A European comparison. Working Paper, No. 06/24, Bradford University.

[48] Sujan, A and Abeysekera, I. (2007), Intellectual capital reporting practices of the top Australian firms, Australian Accounting Review, 17 (2), 71-83.

[49] Joshi, M, Ubha, S, D and Sidhu, J. (2012). Intellectual capital disclosure by Indian and Australian information technology companies "A comparative analysis". Journal of Intellectual capital, 13(4), $582-598$.

[50] Abeysekera, I. (2008). Intellectual capital disclosure trends: Singapore and Sri Lanka. Journal of Intellectual Capital, 9(4), 723-737.

[51] Abeysekera, I. (2007). Intellectual capital reporting between a developing and developed nation. Journal of Intellectual Capital, 8(2), 329-345.

[52] Khan H. and Ali M., (2010). An empirical investigation and users perceptions on intellectual capital reporting in banks: evidence from Bangladesh. Journal of Human Resource Costing and Accounting, 14 (1), 48- 69.

[53] Ahmed Haji, A and Mubaraq, S. (2012). The trend of intellectual capital disclosure: evidence from the Nigerian banking sector. Journal of Human Resource Costing and Accounting, 16(3), 184-209.

[54] Mubaraq, SandAhmed Haji, A. (2014). The impact of corporate governance attributes of intellectual capital disclosure. Journal of Banking Regulation, 15(2), 144-163.

[55] Ousama. A., Fatima, A. H., and Majdi, A. R. (2011). Effects of intellectual capital information disclosed in annual reports on market capitalization: Evidence from BursaMalaysia, Journal of Human Resource Costing \& Accounting, 15 (2), 85-101.

[56] Ousama. A., Fatima, A. H., and Majdi, A. R. (2011). Usefulness of intellectual capital information preparers' and users' views, Journal of Intellectual Capital, 12 (3), 430-445.

[57] Ahmed Haji, A and Mubaraq, S. (2013). The impact of corporate governance attributes of intellectual capital disclosure: A longitudinal investigation of Nigerian banking sector. Journal of Banking Regulation, 16(3), 184-209.

[58] Ahmed Haji A. A. and Ghazali N. A. M. (2012). Intellectual capital disclosure trends: some Malaysian evidence. Journal of Intellectual Capital, 13(3), 377-397.

[59] Ahmed Haji A. A. and Ghazali N. A. M. (2013). A longitudinal examination of intellectual capital disclosures and corporate governance attribute in Malaysia. Asian Review of Accounting, 21 (1), $27-$ 52.

[60] Guthrie, J., Petty, R., and Ricceri, F. (2006). The voluntary reporting on intellectual capital: comparing evidence from Hong Kong and Australia. Journal of Intellectual Capital, 7(2), 254-271.

[61] Jensen, M. and Meckling, W. (1976). Theory of the Firm: managerial Behaviour, Agency Costs and Ownership Structure. Journal of Financial Economics. 305-360.

[62] Haniffa, R., M. and Hudaib, M. (2004). Disclosure practices in Islamic financial institutions. Working paper series of the Bradford University School of Management. 
[63] Kappusamy, K. and Rahman, A,. (2007). A comparative study of Islamic banking in Malaysia, Indonesia, and Brunei: determinants of its growth, Journal of Economic Cooperation, 28(1), 209218.

[64] Lewis, K,. M. (2001). Islam and Accounting. Blackwell Publishers, USA.

[65] Husin, M, N; Hooper, K and Olesen, K. (2012). Analysis of intellectual capital disclosure" an illustrative example. Journal of intellectual capital, 13(2), 196-220.

[66] Guthrie, J., Petty, R., Ferrier, F., and Well, R. (1999, June). There is no Accounting for Intellectual Capital in Australia: A Review of Annual Reporting Practices and the Internal Measurement if Intangibles. Paper Presented at OECD International Symposium on Measuring and Reporting Intellectual Capital: Experience, Issues, and Prospects, Amsterdam.

[67] National Committee of Governance. (2006). Indonesia's Code of Good Corporate Governance. $\begin{array}{lll}\text { Retrieved January } & 3010 .\end{array}$ http://www.bapepam.go.id/pasar_modal/publikasi_pm/info_pm/Indonesia\%20Code\%20of\%20GCG $\% 202006 . p d f$.

[68] Bank Negara Malaysia (2013). Islamic Financial Services Act, Bank Negara Malaysia. Kuala Lumpur.

[69] AAOIFI (2003). Accounting, Auditing and Governance Standards for Islamic Financial Institutions, Accounting and Auditing Organization for Islamic Financial Institutions, Shariah Standards, Bahrain. AAOIFI.

[70] Dahya, J., Lonie, A.A. and Power, D.M. (1996). The case for separating the roles of chairman and CEO: and analysis of stock market and accounting data, Corporate Governance, 4(2), 71-77.

[71] Li, J. and Harrison, J. R. (2008). Corporate governance and national culture: a multi-country study. Corporate Governance, 8 (5), 607-621.

[72] Rashid, A, A, Ibrahim, K, M, Othman, R and See, F, K (2012). IC disclosure in IPO prospectuses: evidence from Malaysia. Journal of Intellectual Capital, 13(1), 57-80.

[73] Abeysekera, I., and Guthrie, J. (2004). Human capital reporting in a developing nation. The British Accounting Review, 36, 251-268.

[74] Hasan, N. and Musa, M,. (2007). An evaluation of Islamic banking development in Malaysia, Journal of Economic Cooperation, 28(1),96-107.

[75] Bank Negara Malaysia (1999). The Central Bank and the Finance in Malaysia - Decade of Change. Kuala Lumpur.

[76] Bank Negara Malaysia (2011). Shari'ah Governance Framework for Islamic Finance Institutions, Bank Negara Malaysia. Kuala Lumpur.

[77] Bank Negara Malaysia (2012). Bank Negara Malaysia Annual Reports 2012, Central Bank of Malaysia. Kuala Lumpur.

[78] Bank Indonesia (2008). Bank Indonesia Annual Reports 2008, Central Bank of Indonesia. Jakarta.

[79] Bank Indonesia (2013). Bank Indonesia Annual Reports 2013, Central Bank of Indonesia. Jakarta.

[80] Guthrie,J and Petty, R. (2000). Intellectual capital: Australian annual reporting practices. Journal of Intellectual capital, 1 (3), 241-251.

[81] April K. A., Bosma P. and Deglon D. A. (2003). IC measurement and reporting: establishing a practice in SA mining. Journal of Intellectual Capital, 4 (2), 165-180.

[82] Goh, P. C., and Lim, K. P. (2004). Disclosing intellectual capital in company annual reports: evidence from Malaysia. Journal of Intellectual Capital, 5(3), 500-510.

[83] Campbell, D., and Rahman, M. R. A. (2010). A longitudinal examination of intellectual capital reporting in Marks \& Spencer annual reports, 1978-2008. The British Accounting Review, 42, 5670.

[84] Shannon, D.M., and Davenport, M.A..(2001). Using SPSS to solve statistical problems: a selfinstruction guide. New Jersey: Prentice-Hall, Inc.

[85] Williams, S. M. (2000). Is a company's intellectual capital performance and intellectual capital disclosure practices related?: Evidence from publicly listed companies from the FTSE 100. Faculty of Management, University of Calgary.

[86] Abdolmohammadi, M. J. (2005). Intellectual capital disclosure and market Capitalization. Journal of Intellectual Capital, 6 (3), 397- 416. 
[87] Bukh, P. N., Nielsen, C., Gormsen, P. and Mouritsen, J. (2005). Disclosure of informational on intellectual capital in Danish IPO prospectuses. Accounting, Auditing, \& Accountability Journal, 18 (6), 713-732.

[88] Shannon, D.M., and Davenport, M.A..(2001). Using SPSS to solve statistical problems: a selfinstruction guide. New Jersey: Prentice-Hall, Inc.

[89] Cerbioni, F., and Parbonetti, A. (2007). Exploring the effects of corporate governance on intellectual capital disclosure: an analysis of European biotechnology companies. Paper presented at the Third International Conference on Corporate Governance, 16(4), 791-826. 